\title{
Elastisitas Penyerapan Tenaga Kerja Di Provinsi Sumatera Selatan
}

\author{
Anton Trianto \\ katon_at@yahoo.com \\ STIE Darusalam Palembang
}

\begin{abstract}
This study aims to analyze the elasticity of employment in the Province of South Sumatra during the period 2011-2015. The calculation of elasticity of labor absorption is obtained from the comparison between the percentage of labor growth to the percentage of economic growth. The data used are secondary data that is the growth of labour and the growth of South Sumatra's GDP. Elasticity ofemployment is used to see how big the response changes in the amount of labor that occurs due to economic growth. The results showed that during the period 2011-2015 the elasticity of employment of South Sumatra Province more in inelastic category, except in year 2013 the category is elastic. This means that economic growth has less responsive to stimulate the increasing number of workers. The percentage of employment growth is less than the percentage of economic growth. In addition, economic growth has not been consistent to be one of the factors triggering stable employment in several districts / cities in South Sumatra.
\end{abstract}

Keywords: Economic Growth, Employment Absorption, Elasticity of employment

\section{PENDAHULUAN \\ Latar Belakang}

Dalam berbagai kajian ilmiah, pembangunan ekonomi sering dikaitkan dan pertumbuhan ekonomi (economic growth). Pembangunan ekonomi tak dapat lepas dari pertumbuhan ekonomi. Pembangunan ekonomi mendorong pertumbuhan ekonomi, dan sebaliknya, pertumbuhan ekonomi memperlancar proses pembangunan ekonomi.

Pertumbuhan ekonomi adalah salah satu faktor penentu keberhasilan dalam pembangunan ekonomi. Budiman (1997: 23-24) mengatakan bahwa tingkat pertumbuhan ekonomi merupakan salah satu indikator untuk mengukur pembangunan di antara 4 indikator lain yaitu pemerataan pendapatan, kualitas hidup, pelestarian lingkungan, dan terciptanya keadilan sosial serta kesinambungan. Oleh karena itu, tingkat pertumbuhan ekonomi telah lama digunakan untuk melihat seberapa jauh tingkat keberhasilan dalam proses pembangunan ekonomi telah dicapai.

Pembangunan ekonomi itu sendiri sebenarnya mengandung arti yang lebih luas dan mencakup perubahan pada tata susunan ekonomi masyarakat secara menyeluruh. Selain peningkatan produksi secara kuantitatif, proses pembangunan lebih mencakup pada perubahan komposisi produksi, perubahan pada pola penggunaan (alokasi) sumber daya produksi di antara sektor-sektor kegiatan ekonomi, perubahan pada pola pembagian (distribusi) kekayaan dan pendapatan berbagai golongan pelaku ekonomi, perubahan kerangka kelembagaan dalam kehidupan masyarakat secara menyeluruh.

Pembangunan ekonomi adalah suatu proses yang bersifat multidimensional yang melibatkan kepada seluruh perubahan besar baik terhadap perubahan struktur ekonomi, perubahan sosial, mengurangi kemiskinan, mengurangi ketimpangan (disparitas) dan pengangguran (Todaro\& Smith, 2014: 113).Pembangunan ekonomi merupakan serangkaian usaha dalam suatu perekonomian untuk mengembangkan kegiatan ekonominya dengan tujuan menciptakan infrastruktur serta menciptakan persaingan antar perusahaan demi mencapai perkembangan yang diharapkan. Sebagai implikasi perkembangan ini, dengan sendirinya kesempatan kerja diharapkan akan bertambah, dan tingkat pendapatan meningkat serta kemakmuran masyarakat menjadi semakin tinggi (Sukirno, 2010:3).

Dalam era otonomi daerah di Indonesia, proses pembangunan ekonomi didesentralisasi-kan ke masing-masing daerah. Setiap daerah diberi kewenangan dalam 
mengatur dan mengelola sumber-sumber daya ekonominya dalam rangka menjalankan proses pembangunan ekonomi.

Pembangunan ekonomi daerah adalah suatu proses dimana pemerintah daerahdan masyarakatnya mengelolasumberdaya yang ada danmembentuksuatu pola kemitraan antarapemerintah daerah dan sektor swasta untuk menciptakansuatu lapangan kerjabaru, sertamerangsangperkembangankegiatanekonomidalamwilayahtersebut (Arsyad, 2010: 108).

Seperti yang telah dikemukakan sebelumnya, salah satu tujuan utama dari pembangunan ekonomi adalah mengurangi tingkat pengangguran. Cara paling efektif untuk menekan angka pengangguran adalah penciptaan kesempatan kerja melalui pembukaan lapangan kerja. Dengan dibukanya lapangan kerja diharapkan penyerapan tenaga kerja dapat meningkat.

Secara teoritis terdapat keterkaitan antara pertumbuhan ekonomi, pembangunan ekonomi dan tingkat penyerapan tenaga kerja. Pada uraian sebelumnya telah disinggung bahwa pembangunan ekonomi dan pertumbuhan ekonomi memiliki hubungan kausalitas. Sementara keterkaitan erat juga ada pada tingkat penyerapan tenaga kerja dan tingkat pertumbuhan ekonomi. Jika pertumbuhan ekonomi meningkat maka berarti terjadi peningkatan kapasistas produksi barang dan jasa dalam suatu wilayah sehingga secara teori peningkatan ini menandakan adanya ekspansi dalam kegiatan produksi yang kemudian meningkatkan penyerapan tenaga kerja di berbagai sektor ekonomi.

Dornbusch, et al(2001: 89) menyatakan bahwa ouput nasional (sebagai representasi dari pertumbuhan ekonomi) merupakan fungsi dari modal fisik, tenaga kerja dan kemajuan teknologi yang dicapai. Faktor penting yang mempengaruhi pengadaan modal fisik adalah investasi, dalam arti bahwa pertumbuhan ekonomi yang tinggi diduga akan membawa dampak positif terhadap tingkat penyerapan tenaga kerja.

Hubungan antara pertumbuhan ekonomi dengan penyerapan tenaga kerja secara teoritis juga ditunjukkan melalui Hukum Okun. Menurut Mankiw (2007: 249-251) Hukum Okun adalah relasi negatif antara pengangguran dan PDB (GDP). Hukum Okun merupakan pengingat bahwa faktor-faktor yang menentukan siklus bisnis pada jangka pendek sangat berbeda dengan faktor-faktor yang membentuk pertumbuhan ekonomi jangka panjang. Hukum Okun (Okun's law) merupakan hubungan negatif antara pengangguran dan PDB, yang mengacu pada penurunan dalam pengangguran sebesar satu persen dikaitkan dengan pertumbuhan tambahan dalam PDB yang mendekati dua persen. Dengan kata lain, Hukum Okun menggambarkan apabila PDB meningkat sebesar dua persen maka akan terjadi peningkatan penyerapan tenaga kerja yang kemudian menurunkan angka pengangguran sebesar satu persen.

Pertumbuhan ekonomibertautan erat dengan peningkatan produksi barang dan jasa, yang antara lain diukur dengan besaran yang disebut Produk Domestik Bruto(PDB) pada tingkat nasional dan Produk Domestik Regional Bruto (PDRB) untuk daerah, baik propinsi maupun kabupaten/kota.

Provinsi Sumatera Selatan adalah salah satu provinsi di Indonesia yang mengalami fluktuatif dalam tingkat pertumbuhan ekonominya. Berdasarkan data BPS, pertumbuhan Provinsi Sumatera Selatan terus mengalami penurunan pada periode 2012-2015. Penurunan ini mengikuti tren penurunan pertumbuhan ekonomi skala nasional. Rata-rata pertumbuhan ekonomi Provinsi Sumatera Selatan selama 2010-2015 adalah 5,6 persen pertahun. 
Tabel 1.1 berikut ini menggambarkan perkembangan PDRB Provinsi Sumatera Selatan dari tahun 2012-2015.

Tabel 1.1

Perkembangan PDRB Provinsi Sumatera Selatan

Periode 2010-2015 (dalam juta Rupiah)

\begin{tabular}{|l|c|c|c|c|c|c|}
\hline \multirow{2}{*}{ PDRB Sumsel } & \multicolumn{7}{|c|}{ Periode } \\
\cline { 2 - 7 } & $\mathbf{2 0 1 0}$ & $\mathbf{2 0 1 1}$ & $\mathbf{2 0 1 2}$ & $\mathbf{2 0 1 3}$ & $\mathbf{2 0 1 4}$ & $\mathbf{2 0 1 5}$ \\
\hline $\begin{array}{l}\text { PDRB atas } \\
\text { dasar harga } \\
\text { konstan 2010 }\end{array}$ & 194.012 .974 & $\begin{array}{c}206.360 .69 \\
9\end{array}$ & 220.459 .198 & 232.353 .629 & $\begin{array}{c}243.228 .56 \\
7\end{array}$ & $\begin{array}{c}254.022 .86 \\
2\end{array}$ \\
\hline $\begin{array}{c}\% \\
\text { Pertumbuhan }\end{array}$ & 5,63 & 6,36 & 6,83 & 5,40 & 4,68 & 4,44 \\
\hline
\end{tabular}

Sumber: Diolah dari “Provinsi Sumatera Selatan Dalam Angka 2016” (BPS)

Berdasarkan data di atas, PDRB Sumsel atas dasar harga konstan 2010 nilainya terus meningkat selama 2010-2015. Akan tetapi, jika melihat angka pertumbuhannya, PDRB Sumsel terus menurun sejak tahun 2012-2015. Hal ini menunjukkan bahwa pertumbuhan ekonomi Provinsi Sumatera Selatan terus mengalami kontraksi dalam 4 tahun terakhir.

Kondisi ekonomi global yang terpuruk berpengaruh terhadap melemahnya harga komoditas ekspor karena permintaan belum cukup kuat. Salah satu sumber perlambatan pertumbuhan ekonomi Sumsel dari sisi permintaan adalah ekspor. Kegiatan ekspor mengalami kontraksi cukup dalam pada periode 2012-2015. Penurunan tersebut terutama disebabkan penurunan nilai ekspor komoditas karet yang memiliki kontribusi terbesar dalam komposisi ekspor Sumatera Selatan (BPS Sumsel, 2016). Melemahnya permintaan pasar dunia terhadap komoditi karet Sumsel sangat berpengaruh terhadap menurunnya pertumbuhan PDRB beberapa kabupaten/kota di Sumatera Selatan terutama pada daerah-daerah penghasil karet utama.

Tabel 1.2 berikut ini menggambarkan perkembangan PDRB kabupaten/kota di Provinsi Sumatera Selatan selama periode tahun 2010-2015.

Tabel 1.2

Perkembangan PDRB Kabupaten/Kota Provinsi Sumatera Selatan Periode 2012-2015 (dalam milyar Rupiah)

\begin{tabular}{|l|c|c|c|c|}
\hline \multirow{2}{*}{ Kabupaten/Kota } & \multicolumn{4}{c|}{ PDRB Atas Dasar Harga Konstan 2010 } \\
\cline { 2 - 5 } & $\mathbf{2 0 1 2}$ & $\mathbf{2 0 1 3}$ & $\mathbf{2 0 1 4}$ & $\mathbf{2 0 1 5}$ \\
\hline Ogan Komering Ulu & $7.376,01$ & $7.704,61$ & $7.987,73$ & $8.230,96$ \\
\hline Ogan Komering Ilir & $14.230,59$ & $15.135,83$ & $15.902,78$ & $16.668,45$ \\
\hline Muara Enim & $26.374,75$ & $28.158,76$ & $29.041,41$ & $31.253,27$ \\
\hline Lahat & $9.479,39$ & $9.937,39$ & $10.317,90$ & $10.537,52$ \\
\hline Musi Rawas & $9.245,29$ & $9.788,57$ & $10.510,08$ & $11.049,70$ \\
\hline Musi Banyuasin & $35.290,94$ & $36.683,31$ & $38.397,35$ & $39.272,81$ \\
\hline Banyuasin & $13.777,76$ & $14.628,96$ & $15.380,59$ & $16.236,00$ \\
\hline Ogan Komering Ulu Selatan & $4.056,98$ & $4.267,95$ & $4.503,08$ & $4.707,44$ \\
\hline Ogan Komering Ulu Timur & $6.951,88$ & $7.435,45$ & $7.821,52$ & $8.354,95$ \\
\hline Ogan Ilir & $5.121,36$ & $5.492,92$ & $5.852,73$ & $6.122,37$ \\
\hline
\end{tabular}




\begin{tabular}{|l|c|c|c|c|} 
Empat Lawang & $2.582,01$ & $2.721,11$ & $2.836,12$ & $2.963,78$ \\
\hline Pali & $3.352,72$ & $3.577,67$ & $3.577,35$ & $3.736,27$ \\
\hline Musi Rawas Utara & $4.104,39$ & $4.190,45$ & $4.606,18$ & $4.759,31$ \\
\hline Palembang & $70.090,31$ & $74.193,37$ & $78.079,09$ & $82.329,66$ \\
\hline Prabumulih & $3.496,88$ & $3.674,19$ & $4.097,01$ & $4.295,41$ \\
\hline Pagar Alam & $1.641,56$ & $1.735,06$ & $1.814,40$ & $1.892,92$ \\
\hline Lubuk Linggau & $2.943,70$ & $3.042,98$ & $3.235,62$ & $3.439,78$ \\
\hline
\end{tabular}

Sumber: BPS, 2016

Dari tabel di atas, Kota Palembang merupakan daerah penyumbang PDRB terbesar di Provinsi Sumatera Selatan dengan rata-rata PDRB selama tahun 2012-2015 adalah sebesar 76.173 milyar rupiah per tahun atau sekitar 32 persen dari total rata-rata PDRB Sumsel per tahun. Daerah penyumbang terbesar bagi PDRB Sumsel lainnya adalah Musi Banyuasin. Selama tahun 2012-2015, Kabupaten Musi Banyuasin menyumbang PDRB sebesar 37. 411 milyar rupiah per tahun atau sekitar 16 persen dari total rata-rata PDRB Sumsel per tahun. Sementara Kota Pagar Alam menjadi daerah penyumbang PDRB terkecil yaitu hanya sebesar 1.771 milyar rupiah per tahun atau sekitar 0,7 persen dari PDRB Sumsel per tahun selama periode 2012-2015.

Seiring menurunnya angka pertumbuhan ekonomi Provinsi Sumatera Selatan, penurunan pertumbuhan ekonomi juga terjadi di sebagian besar kabupaten/kota di Provinsi Sumatera Selatan. Tabel berikut menggambarkan laju pertumbuhan ekonomi yang dicapai kabupaten dan kota di Provinsi Sumatera Selatan selama periode 2012-2015.

Tabel 1.3

Laju Pertumbuhan EkonomiKabupaten/Kota Provinsi Sumatera Selatan Periode 2012-2015

\begin{tabular}{|l|c|c|c|c|c|}
\hline \multirow{2}{*}{\multicolumn{1}{|c|}{ Kabupaten/Kota }} & \multicolumn{4}{c|}{ Pertumbuhan ekonomi } & \multirow{2}{*}{ Rata-Rata } \\
\cline { 2 - 5 } & $\mathbf{2 0 1 2}$ & $\mathbf{2 0 1 3}$ & $\mathbf{2 0 1 4}$ & $\mathbf{2 0 1 5}$ & \\
\hline Ogan Komering Ulu & 5,26 & 4,46 & 3,67 & 3,05 & 4,11 \\
\hline Ogan Komering Ilir & 6,56 & 6,36 & 5,07 & 4,81 & 5,70 \\
\hline Muara Enim & 8,27 & 6,76 & 3,13 & 7,62 & 6,45 \\
\hline Lahat & 5,28 & 4,83 & 3,83 & 2,13 & 4,02 \\
\hline Musi Rawas & 0,85 & 5,88 & 7,37 & 5,13 & 4,81 \\
\hline Musi Banyuasin & 7,25 & 3,95 & 4,67 & 2,28 & 4,54 \\
\hline Banyuasin & 6,15 & 6,18 & 5,14 & 5,56 & 5,76 \\
\hline Ogan Komering Ulu Selatan & 5,26 & 5,20 & 5,51 & 4,54 & 5,13 \\
\hline Ogan Komering Ulu Timur & 7,20 & 6,96 & 5,19 & 6,82 & 6,54 \\
\hline Ogan Ilir & 8,03 & 7,26 & 6,55 & 4,61 & 6,61 \\
\hline Empat Lawang & 6,11 & 5,39 & 4,23 & 4,50 & 5,06 \\
\hline Pali & 7,30 & 6,71 & $-0,01$ & 4,44 & 4,61 \\
\hline Musi Rawas Utara & 2,58 & 2,10 & 9,92 & 3,32 & 4,48 \\
\hline Palembang & 7,75 & 5,85 & 5,24 & 5,44 & 6,07 \\
\hline Prabumulih & 8,32 & 5,07 & 11,51 & 4,84 & 7,44 \\
\hline Pagar Alam & 6,27 & 5,70 & 4,57 & 4,33 & 5,22 \\
\hline Lubuk Linggau & 6,35 & 3,37 & 6,33 & 6,31 & 5,59 \\
\hline
\end{tabular}

Sumber: BPS, 2016 
Seperti yang telah dikemukakan sebelumnya, secara teori, pertumbuhan ekonomi memiliki hubungan terhadap tingkat penyerapan tenaga kerja. Tabel berikut ini menggambarkan keadaan ketenagakerjaan di Provinsi Sumatera Selatan periode 2011-2015.

Tabel 1.4

Keadaan Ketenagakerjaan di Provinsi Sumatera Selatan

Periode 2011-2015

\begin{tabular}{|l|c|c|c|c|c|}
\hline \multicolumn{1}{|c|}{$\begin{array}{c}\text { Keadaan Tenaga } \\
\text { Kerja }\end{array}$} & \multicolumn{5}{|c|}{ Tahun } \\
\cline { 2 - 6 } & $\mathbf{2 0 1 1}$ & $\mathbf{2 0 1 2}$ & $\mathbf{2 0 1 3}$ & $\mathbf{2 0 1 4}$ & $\mathbf{2 0 1 5}$ \\
\hline $\begin{array}{l}\text { Penduduk yang } \\
\text { Bekerja }\end{array}$ & 3.553 .104 & 3.532 .932 & 3.464 .620 & 3.692 .806 & 3.695 .866 \\
\hline Penganggur & 217.569 & 213.441 & 182.376 & 192.868 & 238.921 \\
\hline $\begin{array}{l}\text { Jumlah Angkatan } \\
\text { Kerja }\end{array}$ & 3.770 .673 & 3.746 .373 & 3.646 .996 & 3.885 .674 & 3.934 .787 \\
\hline $\begin{array}{l}\text { Tingkat } \\
\text { Pengangguran (\%) }\end{array}$ & 5,77 & 5,70 & 5,00 & 4,96 & 6,07 \\
\hline
\end{tabular}

Sumber: BPS, 2016

Berdasarkan tabel di atas, jumlah penduduk yang bekerja selama tahun 2011 hingga 2013 mengalami penurunan sebesar 88.484 orang tenaga kerja. Penurunan jumlah penduduk yang bekerja ini dibarengi dengan penurunan jumlah angkatan kerja sejak tahun 2011 hingga 2013 yaitu sebesar 123.677 orang. Tingkat penurunan angkatan kerja yang lebih besar dibanding penurunan jumlah tenaga kerja (penduduk yang bekerja) menyebabkan persentase tingkat pengangguran juga terus turun selama tahun 2011-2013 yaitu dari 5,77 persen menjadi 5 persen. Jumlah penduduk yang bekerja kembali mengalami kenaikan sejak tahun 2014 hingga 2015 yaitu meningkat sebesar 231.246 orang tenaga kerja sejak tahun 2013. Peningkatan jumlah tenaga kerja ini juga diiringi dengan peningkatan jumlah angkatan kerja sebesar 287.791 orang. Porsi peningkatan jumlah penduduk yang bekerja jauh lebih kecil dibanding peningkatan angkatan kerja sehingga mengakibatkan angka pengangguran kembali naik sejak tahun 20132015 yaitu menjadi 6,07 persen.

Berikut ini Gambar 1.2 menunjukkan grafik pertumbuhan ekonomi dan penyerapan tenaga kerja di Sumatera Selatan.

Gambar 1.2

Grafik Pertumbuhan Ekonomi dan Penyerapan Tenaga Kerja Sumatera Selatan Tahun 2012-2015

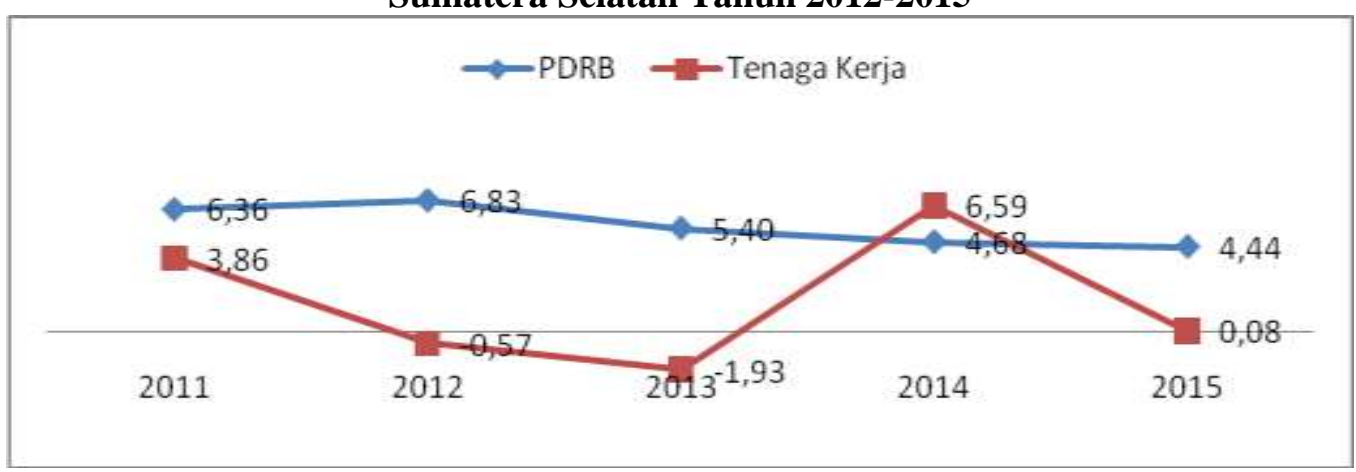

Sumber: Diolah dari data BPS, 2016

Dari gambar di atas terlihat pertumbuhan ekonomi dan penyerapan tenaga kerja Provinsi Sumatera Selatan tidak berjalan dalam tren yang sama. Selama tahun 2011-2012 pertumbuhan ekonomi cenderung naik sementara penyerapan tenaga kerja 
pertumbuhannyamengalami penurunan bahkan hingga mencapai nilai persentase yang negatif. Hal ini artinya jumlah penduduk yang bekerja terus berkurang selama periode tersebut pada saat pertumbuhan ekonomi justru meningkat. Mulai tahun 2012-2015, pertumbuhan ekonomi perlahan terus turun dari tahun sebelumnya dan hal ini diikuti dengan terus memburuknya pertumbuhan penyerapan tenaga kerja hingga mencapai angka $-1,93$ persen. Akan tetapi pada tahun 2014, pertumbuhan jumlah tenaga kerja melonjak drastis dari $-1,93$ persen menjadi 6,59 persen. Kemudian pada tahun 2015 persentase pertumbuhan ekonomi terus menurun seiring dengan melemahnya ekonomi nasional dan internasional. Demikian juga dengan pertumbuhan tenaga kerja kembali menurun tajam menjadi 0,08 persen dari tahun sebelumnya.

Problematika ketenagakerjaan di Provinsi Sumatera Selatan tidak jauh berbeda dengan permasalahan ketenagakerjaan di Indonesia pada umunya. Baik itu menyangkut tingkat pengangguran yang masih relatif tinggi, maupun tingkat produktivitas tenaga kerja yang masih belum optimal. Salah satu tantangan terbesar adalah menciptakan lapangan kerja atau usaha yang layak bagi angkatan kerja yang harus diantisipasi dari sejak dini sebelum terjadi peningkatan karena perubahan struktur umur penduduk. Tantangan itu mencakup dua aspek sekaligus, yaitu penciptaan lapangan kerja baru bagi angkatan kerja yang belum bekerja, dan peningkatan produktivitas kerja bagi mereka yang sudah berkerja sehingga dapat memperoleh imbalan kerja yang memadai untuk dapat hidup secara layak/decent living (BPS, 2016: 2).

Berikut ini tabel 1.5 yang menggambarkan jumlah penduduk yang bekerja menurut kabupaten/kota di Sumatera Selatan tahun 2011-2015.

Tabel 1.5

Jumlah Penduduk Yang Bekerja Menurut Kabupaten/Kota di Sumatera Selatan\

Tahun 2011-2015

\begin{tabular}{|c|c|c|c|c|c|c|c|}
\hline \multirow[b]{2}{*}{ No. } & \multirow[b]{2}{*}{ Kabupaten/Kota } & \multicolumn{5}{|c|}{ Jumlah Penduduk Yang Bekerja (orang) } & \multirow{2}{*}{$\begin{array}{c}\text { Rata- } \\
\text { Rata } \\
\text { Per } \\
\text { Tahun }\end{array}$} \\
\hline & & 2011 & 2012 & 2013 & 2014 & 2015 & \\
\hline 1 & Ogan Komering Ulu & 154.664 & 139.375 & 133.549 & 149.945 & 155.208 & 146.548 \\
\hline 2 & Ogan Komering Ilir & 365.638 & 351.857 & 361.153 & 373.278 & 343.665 & 359.118 \\
\hline 3 & Muara Enim & 342.339 & 350.766 & 341.978 & 350.439 & 282.665 & 333.637 \\
\hline 4 & Lahat & 182.115 & 188.232 & 184.178 & 184.770 & 197.591 & 187.377 \\
\hline 5 & Musi Rawas & 264.596 & 300.588 & 296.100 & 310.699 & 193.051 & 3.007 \\
\hline 6 & Musi Banyuasin & 274.172 & 258.055 & 239.585 & 268.495 & 269.140 & 261.889 \\
\hline 7 & Banyuasin & 362.595 & 334.801 & 323.299 & 367.665 & 360.305 & 349.733 \\
\hline 8 & Oku Selatan & 163.752 & 178.351 & 169.324 & 184.990 & 186.238 & 176.531 \\
\hline 9 & Oku Timur & 312.182 & 314.187 & 288.110 & 294.632 & 321.099 & 306.042 \\
\hline 10 & Ogan Ilir & 184.801 & 204.135 & 202.054 & 205.412 & 202.337 & 199.748 \\
\hline 11 & Empat Lawang & 110.573 & 113.473 & 105.127 & 108.160 & 115.421 & 110.551 \\
\hline 12 & PALI & & & & & 87.253 & 87.253 \\
\hline 13 & Musi Rawas Utara & & & & & 79.422 & 79.422 \\
\hline 14 & Palembang & 619.517 & 579.473 & 600.408 & 661.192 & 663.315 & 624.781 \\
\hline 15 & Prabumulih & 70.795 & 69.746 & 73.231 & 78.001 & 82.887 & 74.932 \\
\hline 16 & Pagar Alam & 58.995 & 63.139 & 58.433 & 62.482 & 72.798 & 63.169 \\
\hline 17 & Lubuk Linggau & 86.370 & 86.754 & 88.091 & 93.246 & 83.471 & 87.586 \\
\hline
\end{tabular}

Sumber: Diolah dari "Sumatera Selatan Dalam Angka 2011-2016” (BPS) 
Jumlah penduduk yang bekerja di berbagai daerah di Sumatera Selatan cenderung mengalami fluktuasi selama tahun 2011-2015. Kota Palembang sebagai daerah pusat pertumbuhan di Sumatera Selatan merupakan daerah yg memiliki rata-rata jumlah penduduk bekerja per tahun paling besar yaitu 624.781 orang tenaga kerja. Sementara Kota Pagar Alam adalah daerah yang memiliki rata-rata jumlah penduduk berkerja per tahun paling kecil yaitu hanya 63.169 orang tenaga kerja.

Masalah penyerapan tenaga kerja dan pengangguran merupakan masalah serius yang harus di perhatikan oleh pemerintah. Faktor utama besarnya angka pengangguran adalah keterbatasan lapangan kerja. Masalah ini sudah pasti akan memberikan tekanan berat pada perekonomian serta dampak buruk bagi sosial seperti kriminalitas dan lain sebagainya. Salah satu langkah strategis pemerintah untuk menciptakan lapangan pekerjaan yang baru agar mengurangi penangguran di Provinsi Sumatera Selatan adalah pemerintah harus menggalang dana investasi baik dari pemerintah daerah, pemerintah pusat, masyarakat maupun investasi luar negeri dengan cara memperbaiki iklim bisnis dan memangkas birokrasi perizinan. Peningkatan investasi diharapkan akan menggairahkan pertumbuhan sektor produksi yang kemudian akan meningkatkan pertumbuhan ekonomi yang tentu saja juga berimbas pada peningkatan penyerapan tenaga kerja akibat terciptanya lapangan kerja baru.

Dalam berbagai kajian ilmiah, salah satu alat yang dipakai untuk menganalisis hubungan antara perumbuhan ekonomi dan penyerapan tenaga kerja adalah elastisitas penyerapan tenaga kerja terhadap pertumbuhan ekonomi. Koefesien elastisitas penyerapan tenaga kerja dapat dihitung dengan menggunakan rumus sebagai berikut: yaitu persentasi pertumbuhan tenaga kerjapertahun dibanding dengan persentasi pertumbuhan PDRB pertahun.

Konsep elastisitas yang dipakai dalam mengkaji kondisi penyerapan tenaga kerja mampu menghadirkan gambaran tentang seberapa besar perubahan jumlah tenaga kerja yang terjadi akibat adanya pertumbuhan ekonomi (pertumbuhan PDRB) pada setiap tahunnya di sebuah daerah. Dengan menggunakan koefisien elastisitas penyerapan tenaga kerja, dapat dinilai seefektif apa pertumbuhan PDRB Kabupaten/Kota di Sumatera Selatan mampu meningkatkan penyerapan tenaga kerja dan mengurangi pengangguran.

Berdasarkan uraian di atas, maka penelitian ini akan mengambil judul Perbandingan Elastisitas Penyerapan Tenaga Kerja di Perovinsi Sumatera Selatan.”

\section{Rumusan Masalah}

Rumusan masalah dalam penelitian ini adalah sebagai berikut:

1. Bagaimanakah tingkat elastisitas penyerapan tenaga kerja di Provinsi Sumatera Selatan

2. Bagaimanakah perbandingan elastisitas penyerapan tenaga kerja antar kabupaten/kota di Sumatera Selatan.

\section{Tujuan Penelitian}

Berdasarkan rumusan masalah di atas maka tujuan penilitian adalah sebagai berikut:

1. Untuk menganalisis elastisitas penyerapan tenaga kerja di Provinsi Sumatera Selatan

2. Untuk menganalisis dan membandingkan elastisitas penyerapan tenaga kerja pada kabupaten/kotadi Provinsi Sumatera Selatan

\section{Manfaat Penelitian}

Adapun manfaat untuk melakukan penelitian ini adalah :

1. Sebagaimasukan kepada instansi pemerintahan dalam perumusan kebijakan khususnya masalah ketenagakerjaan.

2. Sebagai bahan referensi untuk penelitian yang berkaitan dengan topik ini. 


\section{TINJAUAN PUSTAKA}

\section{Landasan Teori \\ Konsep Tenaga Kerja}

Ketenagakerjaan menurut pasal 1 UU No. 13 Tahun 2003 adalah segala hal yang berhubungan dengan tenaga kerja pada waktu sebelum, selama, dan sesudah masa kerja. Hal yang berhubungan dengan tenaga kerja pada waktu sebelum masa kerja misalnya adalah kesempatan kerja, perencanan tenaga kerja dan penempatan tenaga kerja, sedangkan hal sesudah masa kerja, misalnya adalah masalah pensiun.

Sitanggang dan Nachrowi (2004: 25) menyatakan bahwa tenaga kerja adalah sebagian dari keseluruhan penduduk yang secara potensial dapat menghasilkan barang dan jasa. Sehingga dari pernyataan tersebut dapat disimpulkan bahwa tenaga kerja adalah sebagian penduduk yang dapat menghasilkan barang dan jasa bila terdapat permintaan terhadap barang dan jasa.

Tenaga kerja (manpower) adalah penduduk dalam usia kerja (berusia 15-64 tahun) atau jumlah seluruh penduduk dalam suatu negara yang dapat memproduksi barang dan jasa jika permintaan terhadap tenaga kerja mereka, dan jika mau berpartisipasi dalam aktivitas tersebut (Subri, 2012: 59)

Menurut Gunaidi (2005:6) penyerapan tenaga kerja akan membaik apabila perekonomian tumbuh dengan derapyang cepat dibeberapa arah, kenaikan PNB akan memperbesar tingkatpenyerapantenagakerja.Kebijakanterpaduakan mengenai berbagai kebijaksanaan ekonomi dapat mendorong tercapainya tingkat penyerapan tenaga kerja yang tinggi.

\section{Konsep AngkatanKerja, BukanAngkatanKerja dan Tingkat Partisipasi Angkatan Kerja}

Konsep angkatan kerja yang paling luasialah angkatan kerjamenyeluruh atau total labor force, yang dirumuskan sebagai keseluruhan angkatan kerja dari semua individu yang tidak dilembagakan berusia 16 tahun atau lebih tua dalam satu minggu, termasuk angkatan militer, baik tenaganya yang digunakan maupun tidak digunakan (Afrida,2003: 99).

Angkatan kerja adalah penduduk usia kerja (15 tahun dan lebih) yang bekerja, atau punya pekerjaan namun sementara tidak bekerja dan pengangguran (BPS, 2015: xli).Penduduk usia kurang 15 tahun meski telah bekerja untuk memenuhi kebutuhan hidupnya tidaktermasukangkatankerja.Sementara definisi bukan angkatan kerja menurut BPS adalah penduduk usia kerja (15 tahun dan lebih) yang masih sekolah, mengurus rumah tangga atau melaksanakan kegiatan lainnya selain kegiatan pribadi.

Tingkat Partisipasi Angkatan Kerja (TPAK) adalah kelompok penduduk tertentu dimana dapat dihitung dari perbandingan antara jumlah angkatan kerjadengan penduduk dalam usia kerja dalam kelompok yang sama. Tingkat Partisipasi Angkatan Kerja dapat dinyatakan untuk seluruh penduduk dalam usia kerja dan dapat pula dinyatakan untuk suatu kelompok tertentu seperti kelompok laki-laki, kelompok wanita di kota, kelompok tenaga terdidik, kelompok umur 10-14 tahun di desa dan lain-lain (Simanjuntak,1985: 36).

Menurut BPS (2015:5), Tingkat partisipasi angkatan kerja (TPAK) adalah perbandingan antara jumlah penduduk yang termasuk angkatan kerja dengan penduduk usia kerja atau tenaga kerja. Ukuran ini secara kasar dapat menerangkan tentang kecenderungan tenaga kerja untuk aktif bekerja atau mencari kerja yang sifatnya mendatangkan kesempatan berpenghasilan baik berupa uang atau barang. Makin tinggi angka TPAK merupakan indikasi meningkatnya kecenderungan penduduk usia ekonomi aktif (angkatan kerja) untuk mencari pekerjaan atau melakukan kegiatan ekonomi. Jumlah penduduk usia kerja, kebutuhan penduduk untuk bekerja, dan berbagai faktor sosial, ekonomi dan demografis merupakan besaran-besaran yang mempengaruhi TPAK.

\section{Kesempatan Kerja dan Penyerapan Tenaga Kerja}

Kesempatan kerja mengandung pengertian bahwa besarnya kesediaan usaha produksi untuk mempekerjakan tenaga kerja yang dibutuhkan dalam proses produksi, yang dapat berarti lapangan pekerjaan atau kesempatan yang tersedia untuk bekerja yang ada dari suatu saat dari kegiatan ekonomi. Kesempatan kerja dapat tercipta apabila terjadi permintaan tenaga kerja di 
pasar kerja, sehingga dengan kata lain kesempatan kerja juga menujukkan permintaan terhadap tenaga kerja.

Permintaan tenaga kerja berkaitan dengan jumlah tenaga kerja yang di butuhkan oleh perusahaan atau instansti tertentu. Biasanya permintaan tenaga kerja akan di pengaruhi oleh tingkat upah dan perubahan faktor-faktor lain yang mempengaruhi permintaan hasil produksi (Afrida, 2003: 205).

Badan Pusat Statistik (BPS) telah mengembangkan indikator Tingkat Kesempatan Kerja (TKK). Tingkat Kesempatan Kerja adalah indikator yang menggambarkan kesempatan seseorang untuk terserap pada pasar kerja. Dengan kata lain indikator ini menghitung peluang seorang penduduk usia kerja yang termasuk angkatan kerja untuk bekerja. Tingkat Kesempatan Kerja dihitung dengan mencari persentase dari perbandingan antara jumlah penduduk bekerja dengan jumlah angkatan kerja. Rumus Tingkat Kesempatan Kerja adalah sebagai berikut: (https://sirusa.bps.go.id)

$$
T K K=\frac{\text { Jumlah Penduduk Bekerja }}{\text { JumlahAngkatan Kerja }} \times 100 \%
$$

Keterbatasan kesempatan kerja sering kali terjadi karena ketidakmampuan sektor-sektor menampung limpahan tenaga kerja yang disebabkan oleh laju pertumbuhan penduduk. Karena laju pertumbuhan penduduk tidak seimbang dengan pertumbuhan sektor perekonomian kalaupun ada hanya berhasil dalam waktu jangka pendek.

Secara teoritis, ada tiga cara pokok untuk menciptakan kesempatan kerja atau berusaha dalam jangka panjang. Cara pertama adalah dengan memperlambat laju pertumbuhan penduduk yang diharapkan dapat menekan laju pertumbuhan sisi penawaran tenaga kerja. Tetapi seperti dikemukakan di atas, cara ini tidak memadai lagi bagi Indonesia karena angka kelahiran memang telah relatif rendah dan dampaknya terhadap pertumbuhan tenaga kerja kurang signifikan dalam jangka pendek. Cara kedua adalah dengan meningkatkan intensitas pekerja dalam menghasilkan output (labour intensity of output). Tetapi dalam jangka panjang, cara ini tidak selalu berhasil karena tidak selalu kondusif bagi pertumbuhan ekonomi yang berkesinambungan. Cara ketiga adalah melalui pertumbuhan ekonomi. Cara ini bukan tanpa kualifikasi karena secara empiris terbukti bahwa pertumbuhan ekonomi dan kesempatan kerja tidak terdapat hubungan otomatis atau niscaya, tetapi justru tantangannya menjadi riil, karena hubungan yang tidak otomatis itu, maka peranan pemerintah menjadi strategis dan crucial untuk merancang strategi pertumbuhan ekonomi yang tinggi, tetapi juga "ramah" terhadap ketenagakerjaan (Mahalli, 2008: 128).

Pertumbuhan kesempatan kerja tentu akan diiringi dengan naiknya tingkat penyerapan tenaga kerja. Menurut Simanjuntak (2001), penyerapan tenaga kerja adalah penduduk yang bekerja terserap dan tersebar di berbagai sektor.Menurut Kuncoro (2002), penyerapan tenaga kerja adalah banyaknya lapangan kerja yang sudah terisi yang tercermin dari banyaknya jumlah penduduk bekerja.

Sektor yang mempekerjakan banyak orang umumnya menghasilkan barang dan jasa yang relatif besar. Setiap sektor mengalami laju pertumbuhan yang berbeda. Demikian pula dengan kemampuan setiap sektor dalam menyerap tenaga kerja. Perbedaan laju pertumbuhan tersebut mengakibatkan dua hal. Pertama, terdapat perbedaan laju peningkatan produktivitas kerja di masing-masing sektor. Kedua, secara berangsur-angsur terjadi perubahan sektoral, baik dalam penyerapan tenaga kerja maupun dalam kontribusinya dalam pendapatan nasional.

Konsep penyerapan tenaga kerja dalam penelitian ini adalah jumlah penduduk usia kerja yang bekerja dalam berbagai sektor ekonomi. Sementara untuk melihat bagaimana kondisi pertambahan penyerapan tenaga kerja yang terjadi akibat perubahan pertumbuhan ekonomi digunakan elastisitas penyerapan tenaga kerja. 


\section{Konsep Elastisitas Penyerapan Tenaga Kerja}

Menurut Dumairy (2004: 220), konsep elastisitas sebenarnya adalah penerapan ekonomi dari teori diferensiasi dalam matematika. Elastisitas dari suatu fungsi $y=f(x)$ berkenaan dengan $x$ dapat didefinisikan sebagai:

$$
\mathrm{n}=\frac{E_{y}}{E_{x}}=\lim _{\Delta x \rightarrow 0} \frac{(\Delta y / y)}{(\Delta x / x)}=\frac{d y}{d x} \cdot \frac{x}{y}
$$

Ini berarti bahwa elastisitas $y=f(x)$ merupakan limit dari rasio antara perubahan relatif dalam $y$ terhadap perubahan relatif dalam $x$, untuk perubahan $x$ yang sangat kecil atau mendekati nol. Dengan terminologi lain, elastisitas $y$ terhadap $x$ dapat juga dikatakan sebagai rasio antara persentase perubahan $y$ terhadap persentase perubahan $x$.

Menurut Case dan Fair (2007: 109) dalam ilmu ekonomi, dengan logika sederhana kita dapat mengetahui bagaimana perubahan dalam suatu variabel, seperti harga barang atau tingkat bunga cendrung mempengaruhi prilaku. Begitu juga dalam penyerapan tenaga kerja. Jika PDRB suatu sektor meningkat maka permintaan terhadap tenaga kerja di sektor tersebut juga akan meningkat begitu juga sebaliknya jika PDRB mengalami penurunan maka akan terjadi pengurangan tenaga kerja di setiap sektor ekonomi tersebut. Hal ini akan memberikan dampak terhadap penyerapan tenaga kerja dan meningkatnya jumlah penggangguran.

Koefesien elastisitas penyerapan tenaga kerja dapat dihitung dengan menggunakan rumus sebagai berikut: yaitu persentasi pertumbuhan tenaga kerjapertahun dibanding dengan persentasi pertumbuhan PDRB pertahun. Rumus Koefisien elastisitas penyerapan tenaga kerja adalah sebagai berikut:

$$
\text { Elastisitas PTk }=\frac{\% \text { pertumbuhan jumlah tenagakerja }}{\% \text { pertumbuhan ekonomi }(\text { PDRB })}
$$

Secara umum elastisitas adalah suatu pengukuran kuantitatif yang menunjukan sampai dimana besar pengaruh satu variabel terhadap variabel yang lain dalam kurun waktu tertentu dengan nilai koefesien elastisitas berkisar anatara nol dan tak terhingga. Perlu di ingat dalam perhitungan nilai elastisitas tanda minus (-)atau plus (+) sering di abaikan karena nilai yang negatif dikarenakan perubahanvariabel yang satu ke variabelyang lain adalah menggambarkan perubahan kearah yang berbalikan.

Dengan mengadopsi konsep elastisitas, analisis perubahan penyerapan tenaga kerja akibat perubahan pertumbuhan ekonomi akan digolongkan menjadi empat jenis tipe elastisitas yaitu elastis sempurna, inelastis sempurna, elastis,inelastis, dan uniter. Pada kasus elastisitas penyerapan tenaga kerja, penjelasan kategori elastisitas tersebut adalah sebagi berikut:

a. InelastissempurnaadalahperubahanPDRBtidakmengubahjumlahpertumbuhan jumlah tenaga kerja walaupunpertumbuhan PDRBmengalami kenaikan atau penurunan. Nilai keofisien elastisitasnya adalah 0 (nol).

b. Elastis sempurna adalah apabila pertumbuhan jumlah tenaga kerja akan tetap terjadi walaupun tidak terjadi pertumbuhan PDRB. Nilai koefisien elastisitasnya adalah tidak terhingga $(\infty)$.

c. Elastisitas uniter adalah elastisitas yang mempunyai koefesien elastisitas permintaan sebesar 1 (satu). Elastisitas ini menggambarkan keadaan apabila persentase pertumbuhan ekonomi akan sebanding dengan persentase pertumbuhan jumlah tenaga kerja.

d. Tidak elastis (inelastis) adalah keadaan di mana persentase perubahan PDRB lebih besar dari pada persentase perubahan jumlah tenaga kerja. Nilai koefesien elastisitasnyakurang dari 1 (satu).

e. Elastis adalah keadaan di mana persentase perubahanPDRB lebih kecil daripada persentase perubahan jumlah tenaga kerja. Nilai koefesien elastisitasnyalebih dari 1 (satu). 


\section{Produk Domestik Regional Bruto (PDRB)}

Untuk mengukurpertumbuhan ekonomi para ahli ekonom menggunakan data Produk Domestik Bruto (PDB) yang mengukur pendapatan setiap orang dalam perekonomian. Berapa besar perubahan pertumbuhan perekonomian suatu negara diukur dalam kurun waktu pertahun. Apakah pertumbuhanya meningkat atau malah semakin menurun yang disebabkan oleh berbagai faktor-faktor seperti perubahan tenaga kerja, modal, investasi dan sumber daya alam yang tersedia di suatu negara.

Sebagai tolak ukur yang paling banyak dipakai utuk mengukur keberhasilan perekonomian suatu daerah adalah Produk Domestik Regional Bruto(PDRB) adalah hasil produk barang dan jasa orang-orang dan perusahaan. Dinamakan bruto karena memasuki komponen penyusutan. Dinamakan domestik karena batasannya adalah suatu wilayah atau negara, sehingga didalamnya termasuk hasil-hasil barang dan jasa perusahaan serta yang dihitung adalah produksi barang dan jasa.

Produk Domestik Bruto (GDP) mengukur pendapatan dan pengeluaran total pada perekonomian. Karena GDP adalah ukuran yang paling luas untuk keseluruhan kondisi perekonomian (Mankiw, 2007:247).

Menurut Meier dan Rouch (2000) dalam Arsyad (2010:3), selama dekade 1950-an hingga awal dekade1960-an, kebijakan-kebijakan pembangunan ditunjukan terutama sekali pada maksimisasi pertumbuhan Gross National Product (GNP) melalui proses modal dan akumulasi industrilalisasi.

Jumlah nilai akhir produksi barang dan jasa yang dihasilkan oleh sektor-sektor tersebut selama satu tahun fiskal di sebut dengan Gross Domestic Product (GDP) atau Gross National Product (GNP) yang dalam bahasa Indonesianya disebut dengan Produk Domestik Bruto (PDB) atau Produk Nasional Bruto (PNB) (Arsyad, 2010:20)

Dinegara berkembang, yang sering juga digunakan sebagai "Dunia Ketiga" konsep Produk Domestik Bruto adalah konsep yang paling penting kalau dibandingakan pendapatan nasional lainya. Produk Domestik Bruto (PDB) dapat diartikan sebagai nilai barang-barang dan jasa yang diproduksikan di dalam negara tersebut dalam tahun tertentu. Produk Domestik Bruto atau dalam istilah Inggrisnya Gross Domestic Product (GDP), adalah nilai barang dan jasa dalam suatu negara yang diproduksikan oleh faktor-faktor produksi milik warga negara negara tersebut dan negara asing (Sukirno, 2010:34-35).Pendapatan perkapita atau PDRB merupakan jadi tujuan pembangunan ekonomi (economic development) adalah suatu proses kenaikan pendapatan perkapita riil secara terus menerus dalam jangka panjang yang diiringi dengan perubahan kearah yang lebih baik dalam berbagai hal, baik struktur ekonomi ekonomi (menjadi lebih moderen), distribusi kekayaan, sikap, cara pandang terhadap sesuatu, peraturan, kesejahteraan, politik dan lain-lain. Atau dengan kata lain perubahan yang sejalan dan melengkapi juga yang terjadi harus terjadi dalam modal manusia, teknologi, sosial dan kelembagaan agar dapat mewujudkan pertumbuhan ekomomi jangka panjang.

Menurut Tarigan(2007:21) PDRB atau pendapatan regional di bedakan atas dua bentuk yaitu hargaberlaku dan hargakonstan :

a. Pendapatan regional yang didalamnya masih ada unsur inflansinya dinamakan pendapatan regional atas dasar harga berlaku.

b. Pendapatan regional dengan factor inflasi yang sudah ditiadakan merupakan pendapatan regional atas harga konstan, artinya harga produk didasarkan atas harga pada tahun tertentu yang disebut tahun dasar.

\section{Teori Pertumbuhan Ekonomi \\ Teori Neo-klasik}

Teori pertumbuhan neo-klasik melihat dari segi penawaran. Menurut teori yang dikembangkan Abramovits dan Solow, pertumbuhan ekonomi bergantung pada perkembangan faktor-faktor produksi. 
Dalam persamaan, pandangan ini dapat dinyatakan denganpersamaan (Sadono Sukirno, 2010):

$$
\Delta Y=f(\Delta K, \Delta L, \Delta T)
$$

Keterangan:

$\Delta Y=$ tingkat pertumbuhan ekonomi

$\Delta K=$ tingkat pertumbuhan barang modal

$\Delta L=$ tingkat pertumbuhan tenaga kerja

$\Delta T=$ tingkat pertumbuhan teknologi

Analisis Solow selanjutnya membentuk formula matematik untuk persamaan itu dan seterusnya membuat pembuktian secara matematik untuk menunjukkan kesimpulan sebagai berikut:

$$
g=m \cdot \Delta K+b \cdot \Delta L+\Delta T
$$

Keterangan:

$\Delta Y=$ tingkat pertumbuhan ekonomi

$\Delta K=$ tingkat pertumbuhan barang modal

$\Delta L=$ tingkat pertumbuhan tenaga kerja

$\Delta T=$ tingkat pertumbuhan teknologi

$g \quad=$ tingkat persentase pertumbuhan ekonomi

$m \quad=$ produktivitas modal marginal

$b \quad=$ produktivitas marginal tenaga kerja

Persamaan di atas pada hakekatnya menyatakan tingkat pertumbuhan dan pembangunan ekonomi bergantung pada:

1. Pertambahan modal dan produktifitas modal marginal

2. Pertambahan tenaga kerja dan produktifitas tenaga kerja marginal

3. Perkembangan teknologi

Sumbangan terpenting dari teori neo-klasik bukan dalam hal menunjukkan faktor-faktor yang mempengaruhi pertumbuhan ekonomi, tetapi kemungkinanmenggunakan teori tersebut untuk mengadakan penelitian empiris untuk menentukan peranan sebenarnya dari berbagai faktor dalam menciptakan pertumbuhan ekonomi.

\section{Teori Keynes}

Menurut Keynes semakin besar pendapatan nasional, maka semakin besar jumlah pekerjaan yang dihasilkan, demikian juga sebaliknya.Jumlah pekerjaan bergantung pada permintaan efektif.Permintaan efektif menentukan tingkat keseimbangan pekerjaan dan pendapatan.Permintaan efektif adalah permintaan yang disertai oleh kemampuan untuk membayar barang-barang dan jasa-jasa yang diminta tersebut, yang ada dalam perekonomian.Permintaan efektif terdiri dari permintaan konsumsi dan permintaan investasi.

Investasi dapat menengahi antara pendapatan dan konsumsi. Jika jumlah investasi yang dibutuhkan tidak terpenuhi maka harga permintaan akan turun lebih rendah daripada harga penawaran agregat. Akibatnya pendapatan dan konsumsi akan turun sampai ditengahi oleh investasi. Jumlah investasi bergantung pada efisiensi marginal dari modal dan suku bunga.

\section{Teori Harrod-Domar}

Modelpertumbuhan Harrod-Domar merupakanmodelhubungan ekonomi funsional yang menyatakanbahwatingkatpertumbuhan ProdukDomestik Bruto (growth)bergantung langsung padatingkattabungan nasionalneto (saving)dan berbanding terbalik dengan rasiomodaloutputnasional (capital)(Todarodan Smith, 2014: 136).

Teori ini pada hakekatnya berusaha menerangkan syarat yang diperlukan agar suatu perekonomian mencapai pertumbuhan yang kuat (steady growth) yaitu pertumbuhan yang akan 
selalu menciptakan penggunaan alat-alat modal dan akan selalu berlaku dalam perekonomian.

Dalam teori ini pembentukan modal dipandang sebagai suatu pengeluaran yang akan menambah kemampuan suatu perekonomian dalam menghasilkanbarang-barang maupun sebagai pengeluaran yang akan menambah permintaan efektif masyarakat (menaikkan pendapatan nasional). Menurut Harrod-Domar ada hubungan ekonomi yang langsung antara besarnya stok modal $(K)$ dan jumlah produksi nasional $(Y)$.

\section{Hubungan Pertumbuhan Ekonomi Terhadap Penyerapan Tenaga Kerja}

Pada uraian sebelumnya telah dikemukakan bahwa adanya kaitan erat antra pertumbuhan ekonomi dengan penyerapan tenaga kerja. Jika pertumbuhan ekonomi meningkat maka berarti terjadi peningkatan kapasistas produksi barang dan jasa dalam suatu wilayah sehingga secara teori peningkatan ini menandakan adanya ekspansi dalam kegiatan produksi yang kemudian meningkatkan penyerapan tenaga kerja di berbagai sektor ekonomi.

Dornbusch, et al (2001: 89) menyatakan bahwa ouput nasional (sebagai representasi dari pertumbuhan ekonomi) merupakan fungsi dari modal fisik, tenaga kerja dan kemajuan teknologi yang dicapai. Faktor penting yang mempengaruhi pengadaan modal fisik adalah investasi, dalam arti bahwa pertumbuhan ekonomi yang tinggi diduga akan membawa dampak positif terhadap tingkat penyerapan tenaga kerja.

Hubungan antara pertumbuhan ekonomi dengan penyerapan tenaga kerja secara teoritis juga ditunjukkan melalui Hukum Okun.Menurut Mankiw (2007: 249-251), Hukum Okun adalah relasi negatif antara pengangguran dan PDB (GDP).Hukum Okun merupakan pengingat bahwa faktor-faktor yang menentukan siklus bisnis pada jangka pendek sangat berbeda dengan faktor-faktor yang membentuk pertumbuhan ekonomi jangka panjang.Hukum Okun (Okun's law) merupakan hubungan negatif antara pengangguran dan PDB, yang mengacu pada penurunan dalam pengangguran sebesar satu persen dikaitkan dengan pertumbuhan tambahan dalam PDB yang mendekati dua persen. Dengan kata lain, Hukum Okun menggambarkan apabila PDB meningkat sebesar dua persen maka akan terjadi peningkatan penyerapan tenaga kerja yang kemudian menurunkan angka pengangguran sebesar satu persen.

Pertumbuhan ekonomi yang tidak mendorong penyerapan tenaga kerja akan menyebabkan terjadinya masalah pengangguran dan kemiskinan yang bisa berujung pada timbulnya ketidakstabilan sosial. Sementara penyerapan tenaga kerja yang tidak mendorong terjadinya pertumbuhan ekonomi akan menciptakan gangguan dalam tercapainya pertumbuhan ekonomi yang berkelanjutan.

Dalam model sederhana tentang pertumbuhan ekonomi, pada umumnya pengertian tenaga kerja diartikan sebagai angkatan kerja yang bersifat homogen.Menurut Lewis, angkatan kerja yang homogen dan tidak terampil dianggap bisa bergerak dan beralih dari sektor tradisional ke sektor modern secara lancar dan dalam jumlah tidak terbatas. Dalam keadaan demikian, peranan pertumbuhan ekonomi mengandung sifat elastisitas yang tinggi.Meningkatnya permintaan atas tenaga kerja (dari sektor tradisional) bersumber dari ekspansi kegiatan sektor modern.Dengan demikian salah satu faktor yang berpengaruh terhadap penyerapan tenaga kerja adalah pertumbuhan ekonomi.

Upaya meningkatkan pertumbuhan ekonomi yang mampu menciptakan lapangan kerja yang optimal dari segi jumlah, produktivitas dan efisiensi memerlukan kebijakan yang memperhitungkan kondisi internal maupun perkembangan eksternal. Kondisi tersebut merunpakan input bagi pengambil keputusan (Asaddin dan Mansoer, 2001).

\section{Penelitian Terdahulu}

Yanurwardhani dan Woyanti (2009) melakukan penelitian tentang pengaruh faktor ekonomi terhadap penyerapan tenaga kerja pada industri kecil tempe di Kota Semarang. Penelitian ini bertujuan untuk menganalisis pengaruh modal kerja, nilai produksi, dan tingkat upah terhadap penyerapan tenaga kerja pada industri kecil tempe di Semarang. Data yang digunakan adalah data primer melalui wawancara langsung terhadap 58 pengusaha tempe di Semarang. Teknik analisis yang diganakan adalah regresi linier berganda. Hasil yang didapat 
adalah mengatakan bahwa variabel modal kerja, nilai produksi dan tingkat upah berpengaruh signifikan terhadap penyerapan tenaga kerja pada industri kecil tempe di Semarang. Variabel modal kerja dan nilai produksi berpengaruh positif terhadap penyerapan tenaga kerja sedangkan variabel upah memiliki pengaruh negatif.

Chusna (2013) mengkaji tentang pengaruh laju pertumbuhan sektor industri, investasi, dan upah terhadap penyerapan tenaga kerja sektor industri di provinsi jawa tengah tahun 19802011. Tujuan penelitian ini adalah untuk mengetahui gambaran umum dan pengaruh pertumbuhan sektor industri, investasi dan upah terhadap penyerapan tenaga kerja sektor industri di Jawa Tengah. Penelitian ini dianalisis menggunakan analisis regresi linear berganda. Kesimpulan dari penelitian ini menunjukkan bahwa pertumbuhan sektor industri menunjukkan tren yang semakin menurun sedangkan investasi, upah dan penyerapan tenaga kerja sektor industri menunjukkan tren yang semakin meningkat, laju pertumbuhan sektor industri tidak berpengaruh terhadap penyerapan tenaga kerja sektor industri, sedangkan investasi dan upah berpengaruh terhadap penyerapan tenaga kerja sektor industri di Jawa Tengah.

Pangastuti (2015) melakukan penelitian tentang analisis faktor faktor yang mempengaruhi penyerapan tenaga kerja di provinsi jawa tengah tahun 2008-2012. Tujuan dari penelitian ini untuk menganalisis pengaruh PDRB, Upah minimum Kabupaten/ Kota (UMK), Pengangguran, serta Pendapatan Asli Daerah (PAD) terhadap penyerapan tenaga di Provinsi Jawa Tengah tahun 2008-2012. Metode pengumpulan data yang digunakan dalam penelitian ini adalah studi dokumentasi, sehingga tidak diperlukan teknik sampling serta kuesioner. Analisis kuantitatif dalam penelitian ini menggunakan regresi linier berganda dengan Metode Random Effect (REM). Hasil penelitian menunjukan pengaruh PDRB terhadap penyerapan tenaga kerja memiliki hubungan yang negatif terhadap penyerapan tenaga kerja. Sementara UMK, pengangguran dan PAD memiliki pengaruh positif terhadap penyerapan tenaga kerja. Variabel PDRB, Upah Minimum Kabupaten/Kota (UMK), serta Pendapatan Asli Daerah (PAD) tidak berpenengaruh signifikan terhadap penyerapan tenaga kerja. Sementara variabel penganguran berpengaruh signifikan terhadap penyerapan tenaga kerja. Oleh karena itu, perlu dikajinya faktor-faktor lain yang dapat mempengaruhi penyerapan tenaga kerja di Jawa Tengah antara lain jumlah perusahaan, nilai produksi, suku bunga dan lain sebagainya.

Darman (2013) mengkaji tentang pengaruh pertumbuhan ekonomi terhadap tingkat pengangguran: analisis Hukum Okun. Penelitian ini menggunakan data time series tahun 19902013. Metode yang digunakan adalah difference version hukum Okun untuk mendapatkan koefisien Okun dan analisis Ordinary Least Square (OLS) untuk mendapatkan koefisien regresi. Dalam kerangka ekonomi makro, hukum Okun menyatakan bahwa apabila GDP tumbuh sebesar 2,5\% diatas trendnya, yang telah dicapai pada tahun tertentu, tingkat pengangguran akan turun sebesar $1 \%$. Dari berbagai penelitian yang dilakukan oleh beberapa peneliti dapat diketahui bahwa koefisien Okun di tiap-tiap Negara berbeda. Di Indonesia, literatur ilmiah yang khusus mengangkat Hukum Okun belum ada, maka penelitian ini bertujuan untuk melihat bagaimana penerapan Hukum Okun di Indonesia. Hasil penelitian menunjukkan bahwa hukum Okun berlaku di Indonesia, dimana koefisien Okun bernilai negatif. Tingkat pengangguran cenderung meningkat seiring dengan dicapainya pertumbuhan GDP.

Dimas dan Woyanti (2009), melakukan penelitian tentang penyerapan tenaga kerja di DKI jakarta. Tujuan penelitian ini adalah untuk menganalisis pengaruh pertumbuhan GDP (PDRB), upah dan investasi terhadap penyerapan tenaga kerja di Kota Jakarta tahun 1990-2004. Teknik analisis yang digunakan adalah regresi linier berganda. Hasil menunjukkan bahwa pertumbuhan GDP memiliki pengaruh positif terhadap penyerapan tenaga kerja di Jakarta, sedangkan variabel upah dan investasi berpengaruh negatif terhadap penyerapan tenaga kerja. Pengaruh negatif ini diakibatkan oleh investasi yang masuk lebih menitikberatkan kepada bisnis padat modal dibanding padat karya sehingga investasi tidak meningkatkan penyerapan tenaga kerja.

Sobita dan Suparta (2014) melakukan penelitian tentang pertumbuhan ekonomi dan penyerapan tenaga kerja di Lampung. Penelitian ini bertujuan untuk menganalisis pengaruh variabel independen PDRB riil, Upah riil, harga Modal bidang pertanian, dan Indeks Harga 
Implisit terhadap variabel dependen Penyerapan Tenaga Kerja di Provinsi Lampung. Penelitian ini menggunakan data sekunder yaitu data PDRB riil, Upah riil, harga Modal di bidang pertanian, dan Indeks Harga Implisit dari 10 Kabupaten/Kota di Provinsi Lampung periode 2008-2012. Metode analisis data yang digunakan adalah analisis data kuantitatif (statistik) dengan menggunakan analisis data panel. Hasil penelitian ini menunjukan bahwa variabel independen PDRB riil dan harga Modal di bidang pertanian secara signifikan berpengaruh positif terhadap penyerapan tenaga kerja. Kenaikan PDRB riil dan Modal di bidang pertanian akan meningkatkan penyerapan tenaga kerja. Sementara itu Variabel Upah riil secara signifikan berpengaruh negatif terhadap penyerapan tenaga kerja. Kenaikan Upah riil akan menurunkan penyerapan tenaga kerja.

\section{Kerangka Pikir}

Bagan kerangka pikir dalam penelitian ini adalah sebagai berikut:

Gambar 2.1

Kerangka Pikir

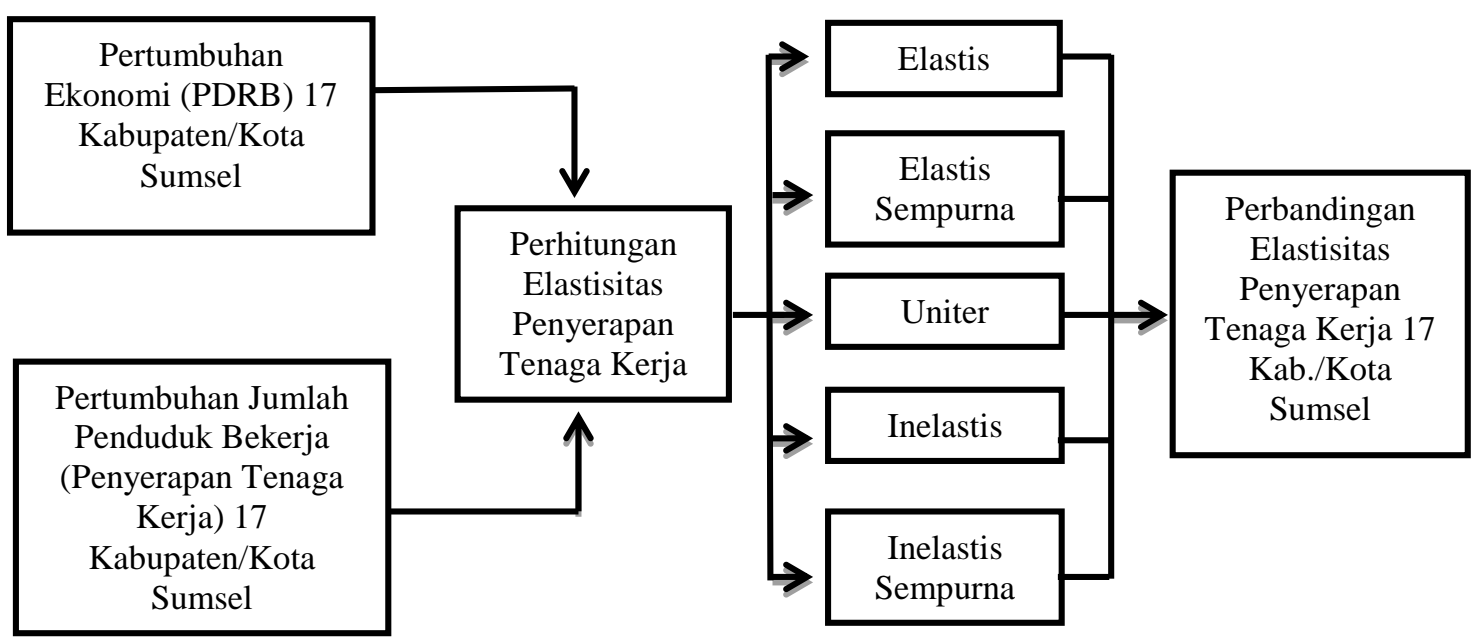

Analisis pada penelitian ini dimulai dengan membahas data pertumbuhan ekonomi kabupaten/kota di Sumatera Selatan yang diwakili oleh data pertumbuhan PDRB-nya, serta data penyerapan tenaga kerja kabupaten/kota di Sumatera Selatan yang diwakili data jumlah penduduk yang bekerja. Selanjutnya dilakukan perhitungan koefisien elastisitas penyerapan tenaga kerja lalu digolongkan tipe elastisitasnya (elastis, inelastis, elastis sempurna, inelastis sempurna, atau uniter). Pada tahap akhir pembahasan akan dilakukan analisis perbandingan elastisitas penyerapan tenaga kerja 17 kabupaten/kota di Provinsi Sumatera Selatan.

\section{METODOLOGI PENELITIAN}

\section{RuangLingkupPenelitian}

Penelitian ini menitikberatkan pada masalah ketenagakerjaan di Provinsi Sumatera Selatan dengan mengkaji seberapa besar elastisitas perubahan penyerapan tenaga kerja terhadap perubahan pertumbuhan PDRB di 17 kabupaten/kota di Sumatera Selatan pada periode tahun 2011-2015. Dalam penelitian ini akan dilakukan perbandingan elastisitas penyerapan tenaga kerja antar kabupaten/kota di Sumatera Selatanpada periode tahun 2011-2015.

\section{Jenis dan Sumber Data}

Jenis data yang digunakan dalam penelitian ini adalah data sekunder yang dirilis oleh Badan Pusat Statistik (BPS) Provinsi Sumatera Selatan. Data yang dikumpulkan merupakan data Produk Domestik Regional Bruto (PDRB) atas harga konstan 2010, data jumlah penduduk yang bekerja di 17 kabupaten/kota Provinsi Sumatera Selatan. Data yang diteliti adalah data periode tahun 2011-2015. Alasan dipilihnya periode tahun tersebut adalah untuk menyesuaikan dengan perubahan tahun dasar yang terjadi pada perhitungan data PDRB. 


\section{Metode Pengumpulan Data}

Dalam penelitian ini metode pengumpulan data yang digunakan melalui pendekatan kepustakaan (Library Research) yakni dilakukan dengan mendapatkan data sekunder yang berasal dari data instansi yang terkait.

\section{Definisi Operasional Datal}

Definisi operasional variabel pada penelitian ini adalah sebagai berikut:

1. Pertumbuhan ekonomi adalah peningkatan produksi barang dan jasa, yang diukur dengan besaran yang disebut produk domestik bruto (PDB) pada aras nasional dan produk domestik regional bruto (PDRB) untuk daerah, baik propinsi maupun kabupaten/kota.

2. Tenaga kerja adalah penduduk dalam usia kerja (berusia 15-64 tahun) atau jumlah seluruh penduduk dalam suatu negara yang dapat memproduksi barang dan jasa.

3. Angkatankerjaadalahpendudukberumur15tahunkeatasyangbekerja, sementaratidakbekerjaatausedang mencaripekerjaan.

4. Bekerja adalah melakukan pekerjaan dengan maksud memperoleh atau membantu memperoleh pendapatan (keuntungan) dan lamanya bekerja paling sedikit 1 jam secara terus menerus dalam seminggu yang lalu (termasuk pada pekerjaan keluarga tanpa upah yang membantu dalam suatu usaha/kegiatan ekonomi).

5. Penyerapan tenaga kerja adalah jumlah penduduk usia kerja yang bekerja dalam berbagai sektor ekonomi. Jumlah penyerapan tenaga kerja dalam penelitian ini diwakilkan oleh jumlah penduduk yang bekerja dalam satu periode.

6. Elastisitas penyerapan tenaga kerja adalah persentasi pertumbuhan tenaga kerjapertahun dibanding dengan persentasi pertumbuhan PDRB pertahun.

\section{Teknik Analisis Data}

Langkah pertama analisis dalam penelitian ini adalah dengan menghitung pertumbuhanpenyerapan tenaga kerja dan pertumbuhan PDRB diSumatera dengan menggunakan rumus sebagai berikut (Arsyad,2010:23).

$$
g l=\frac{l_{t}-l_{t-1}}{l_{t-1}} \times 100 \% \ldots .(1)
$$

Keterangan:

$g l=$ pertumbuhan penduduk yang bekerja

It $=$ jumlah penduduk yang bekerja pada tahun hitung

lt-1 = jumlah penduduk yang bekerja pada tahun sebelumnya

$$
g Y=\frac{Y_{t}-Y_{t-1}}{Y_{t-1}} \times 100 \%
$$

Keterangan:

$g Y=$ pertumbuhan $P D R B$

$Y t=$ jumlah $P D R B$ pada tahun hitung

$Y t-1=$ jumlah PDRB pada tahun sebelumnya

Untuk mengetahui elastisitas penyerapan tenaga kerja maka dapat di pakai rumus elstisitas. Elastisitas adalah konsep umum yang bisa digunakan untuk mengkuantifikasi tanggapan suatu variabel ketika variabel lain berubah. Jika suatu variabel A berubah sebagai tanggapan atas perubahan dalam variabel lain B, elastis A terhadap B sama dengan perubahan presentase dalam A dibagi denganperubahan presentase dalam B(Case dan Fair,2007:110). Rumus Elastisitas Penyerapan Tenaga Kerja adalah sebagai berikut:

$$
E=\frac{g l}{g Y} \ldots \text { (3) }
$$


Keterangan:

$E \quad=$ Elastisitas Penyerapan Tenaga Kerja

$g l=$ Pertumbuhan Jumlah Penduduk Yang Bekerja

$g Y=$ Pertumbuhan PDRB

Setelah melakukan perhitungan elastisitas penyerapan tenaga kerja, selanjutnya akan dilakukan perbandingan nilai koefisien elastisitas antar kabupaten/kota di Sumatera Selatan. Perbandingan ini dilakukan untuk melihat bagaimana elastisitas penyerapan tenaga kerja akibat persentase perubahan pertumbuhan ekonomi di masing-masing kabupaten/kota.

\section{HASIL DAN PEMBAHASAN}

\section{Elastisitas Penyerapan Tenaga Kerja Provinsi Sumatera Selatan}

Seperti yang telah dijelaskan sebelumnya, elastisitas penyerapan tenaga kerja menggambarkan seberapa besar porsi perubahan pertumbuhan jumlah tenaga kerja yang terjadi terhadap porsi perubahan pertumbuhan ekonomi. Tabel di bawah ini menyajikan hasil perhitungan elastisitas penyerapan tenaga kerja terhadap pertumbuhan ekonomi di Provinsi Sumatera Selatan tahun 2011-2015.

Tabel 4.1

Elastisitas Penyerapan Tenaga Kerja Provinsi Sumatera Selatan

Tahun 2011-2015

\begin{tabular}{|c|c|c|c|c|}
\hline Tahun & $\begin{array}{c}\text { Pertumbuhan } \\
\text { Ekonomi (\%) }\end{array}$ & $\begin{array}{c}\text { Pertumbuhan } \\
\text { Tenaga Kerja (\%) }\end{array}$ & Elastisitas & Kategori \\
\hline 2011 & 6,36 & 3,86 & 0,61 & Inelastis \\
\hline 2012 & 6,83 & $-0,57$ & $-0,08$ & Inelastis \\
\hline 2013 & 5,40 & $-1,93$ & $-0,36$ & Inelastis \\
\hline 2014 & 4,68 & 6,59 & 1,41 & Elastis \\
\hline 2015 & 4,44 & 0,08 & 0,02 & Inelastis \\
\hline
\end{tabular}

Berdasarkan perhitungan pada tabel di atas, didapati selama periode 2011-2015 elastisitas tenaga kerja lebih banyak masuk dalam kategori inelastis, hanya pada tahun 2013 kategorinya elastis. Hal ini berarti pertumbuhan ekonomi tidak terlalu mendorong respon pertumbuhan jumlah tenaga kerja.

Nilai elastisitas penyerapan tenaga kerja di Sumatera Selatan pada tahun 2011 adalah 0,61 dan termasuk kategori inelastis. Hal ini berarti porsi pertumbuhan ekonomi lebih besar dari porsi pertumbuhan tenaga kerja. Dengan kata lain, pada tahun 2011 besarnya pertumbuhan ekonomi cenderung mendorong peningkatanjumlah penyerapan tenaga kerja yng nilai persentasenya sebesar 61 persen dari persentasepertumbuhan ekonomi itu sendiri dengan serapan tenaga kerja sebanyak 3.553 .104 orang atau bertambah 131.911 orang tenaga kerja dibanding tahun sebelumnya.

Pada tahun 2012, elasitisitas penyerapan tenaga kerja bernilai negatif yang artinya bahwa pertumbuhan ekonomi memiliki hubungan terbalik terhadap pertumbuhan penyerapan tenaga kerja. Pada tahun tersebut, pertumbuhan ekonomi naik 6,83 persen akan tetapi pertumbuhan penyerapan tenaga kerja justru turun dan tumbuh negatif sebesar $-0,57$ persen. Nilai elastisitasnya adalah $-0,08$ dan masuk dalam kategori inelastis. Hal ini berarti peningkatan pertumbuhan ekonomi justru mendorong penurunan penyerapan tenaga kerja. Pada tahun tersebut, tampaknya pertumbuhan ekonomi yang meningkat tidak mampu meningkatkan penyerapan tenaga kerja di Sumatera selatan. Jumlah tenaga kerja yang terserap dari seluruh sektor perekonomian Sumatera Selatan adalah 3.532.932tenaga kerja. Jumlah tersebut 
menunjukkan penyerapan tenaga kerja Sumatera Selatan berkurang sebanyak 20.172 orang tenaga kerja dari tahun sebelumnya.

Keadaan pada tahun 2013 semakin tidak baik. Pertumbuhan ekonomi mengalami penurunan menjadi 5,40 persen sementara pertumbuhan penyerapan tenaga kerja juga semakin anjlok menjadi $-1,93$ persen dari tahun sebelumnya. Nilai elastisitasnya adalah $-0,36$ dan tergolong inelastis. Penurunan pertumbuhan ekonomi tampaknya berdampak pada semakin rendahnya pertumbuhan penyerapan tenaga kerja. Jumlah tenaga kerja yang terserap pada tahun tersebut adalah sebanyak sebesar3.464.620 atau berkurang 68.312 orang tenaga kerja dari tahun sebelumnya. Angka negatif pada nilai elastisitas menunjukkan bahwa pertumbuhan ekonomi masih dapat tumbuh dengan nilai yang positif walaupun persentasenya turun sedangkan penyerapan tenaga kerja tumbuh dengan nilai yang negatif yang artinya tidak terjadi sama sekali pertambahan tenaga kerja dalam perekonomian justru malah terjadi pengurangan.

Di tengah melemahnya perekonomian akibat krisis global pada tahun 2014, terjadi lonjakan drastis pada pertumbuhan penyerapan tenaga kerja dari -1,93 persen di tahun sebelumnya menjadi 6,59 persen di antara pertumbuhan ekonomi yang berkontraksi sebesar 4,44 persen. Nilai elastisitas mencapai angka 1,41 dan masuk ke dalam kategori elasitis yang artinya persentase pertumbuhan ekonomi lebih kecil dari persentase pertumbuhan tenaga kerja Sumatera Selatan. Jumlah tenaga kerja yang terserap pada periode ini adalah sebesar 3.692.806 orang tenaga kerja atau bertambah sebanyak 228.186 orang tenaga kerja dari tahun sebelumnya. Hal ini dapat disebabkan oleh adanya ekspektasi yang cukup tinggi terhadap kinerja pemerintahan yang baru terpilih pada pemilu 2014 sehingga sektor usaha merespon positif dengan pembukaan lapangan kerja baru walaupun tidak cukup mampu meng-katrol pertumbuhan ekonomi akibat masih lemahnya permintaan global terhadap sektor-sektor primadona di Sumatera Selatan seperti sektor perkebunan karet dan sawit.

Krisis global masih sangat mempengaruhi pertumbuhan ekonomi nasional dan Sumatera Selatan pada tahun 2015. Pertumbuhan ekonomi Sumatera Selatan masih terpuruk pada angka 4,44 persen. Pertumbuhan tenaga kerja pun turun drastis menjadi 0,08 persen dari tahun sebelumnya. Elasitistas penyerapan tenaga kerja mencapai nilai 0,02 dan tergolong kategori inelastis atau persentase pertumbuhan ekonomi masih lebih besar dibanding persentase pertumbuhan tenaga kerja. Dengan kata lain, lesunya pertumbuhan ekonomi mendorong tersendatnya pertumbuhan penyerapan tenaga kerja. Jumlah tenaga kerja yang terserap pada periode ini adalah sebanyak 3.695.866 tenaga kerja. Jumlah ini hanya meningkat sebanyak 3.060tenaga kerja atau sekitar 2 persen dari jumlah tenaga kerja pada tahun sebelumnya.

\section{Perbandingan Elastisitas Penyerapan Tenaga Kerja Antar Kabupaten Kota di Sumatera Selatan}

Pada bagian ini akan dibahas nilai dan perbandingan elastisitas penyerapan tenaga yang dicapai oleh kabupaten dan kota di Provinsi Sumatera Selatan. Pada bagian awal telah dibahas tentang pertumbuhan ekonomi yang dicapai masing-masing kabupaten dan kota di Sumatera Selatan. Tabel 4.2 berikut ini menyajikan perkembangan pertumbuhan tenaga kerja pada masing-masing kabupaten dan kota di Sumatera Selatan.

Tabel 4.2

Elastisitas Penyerapan Tenaga Kerja

Pada Kabupaten/Kota Provinsi Sumatera Selatan Tahun 2011-2015

\begin{tabular}{|l|c|c|c|c|c|c|c|c|c|c|}
\hline \multirow{3}{*}{ Kabupaten/Kota } & \multicolumn{9}{|c|}{ Elastisitas Penyerapan Tenaga Kerja } \\
\cline { 2 - 11 } & \multicolumn{2}{|c|}{2011} & \multicolumn{2}{c|}{2012} & \multicolumn{2}{c|}{$\mathbf{2 0 1 3}$} & \multicolumn{2}{c|}{$\mathbf{2 0 1 4}$} & \multicolumn{2}{c|}{2015} \\
\cline { 2 - 11 } & Nilai & Kategori & Nilai & Kategori & Nilai & Kategori & Nilai & Kategori & Nilai & Kategori \\
\hline Ogan Komering Ulu & 2,03 & Elastis & $-1,88$ & Elastis & $-0,94$ & Inelastis & 3,35 & Elastis & 1,15 & Elastis \\
\hline Ogan Komering Ilir & 2,35 & Elastis & $-0,57$ & Inelastis & 0,42 & Inelastis & 0,66 & Inelastis & $-1,65$ & Elastis \\
\hline Muara Enim & 0,47 & Inelastis & 0,30 & Inelastis & $-0,37$ & Inelastis & 0,79 & Inelastis & $-2,54$ & Elastis \\
\hline
\end{tabular}




\begin{tabular}{|c|c|c|c|c|c|c|c|c|c|c|}
\hline Lahat & $\begin{array}{c}- \\
0,23\end{array}$ & Inelastis & 0,64 & Inelastis & $-0,45$ & Inelastis & 0,08 & Inelastis & 3,26 & Elastis \\
\hline Musi Rawas & 0,58 & Inelastis & 16,00 & Elastis & $-0,25$ & Inelastis & 0,67 & Inelastis & $-7,38$ & Elastis \\
\hline Musi Banyuasin & 7,95 & Elastis & $-0,81$ & Inelastis & $-1,81$ & Elastis & 2,58 & Elastis & 0,11 & Inelastis \\
\hline Banyuasin & 0,24 & Inelastis & $-1,25$ & Elastis & $-0,56$ & Inelastis & 2,67 & Elastis & $-0,36$ & Inelastis \\
\hline $\begin{array}{l}\text { Ogan Komering Ulu } \\
\text { Selatan }\end{array}$ & $\begin{array}{c}- \\
0,85 \\
\end{array}$ & Inelastis & 1,69 & Elastis & $-0,97$ & Inelastis & 1,68 & Elastis & 0,15 & Inelastis \\
\hline $\begin{array}{l}\text { Ogan Komering Ulu } \\
\text { Timur }\end{array}$ & 0,01 & Inelastis & 0,09 & Inelastis & $-1,19$ & Elastis & 0,44 & Inelastis & 1,32 & Elastis \\
\hline Ogan Ilir & $\begin{array}{c}- \\
1,09 \\
\end{array}$ & Elastis & 1,30 & Elastis & $-0,14$ & Inelastis & 0,25 & Inelastis & $-0,32$ & Inelastis \\
\hline Empat Lawang & 1,78 & Elastis & 0,43 & Inelastis & $-1,36$ & Elastis & 0,68 & Inelastis & 1,49 & Elastis \\
\hline \multicolumn{11}{|l|}{ Pali *) } \\
\hline \multicolumn{11}{|l|}{$\begin{array}{l}\text { Musi Rawas Utara } \\
\left.{ }^{*}\right)\end{array}$} \\
\hline Palembang & 0,92 & Inelastis & $-0,83$ & Inelastis & 0,62 & Inelastis & 1,93 & Elastis & 0,06 & Inelastis \\
\hline Prabumulih & 2,02 & Elastis & $-0,18$ & Inelastis & 0,99 & Inelastis & 0,57 & Inelastis & 1,29 & Elastis \\
\hline Pagar Alam & $\begin{array}{c}- \\
1,87\end{array}$ & Elastis & 1,12 & Elastis & $-1,31$ & Elastis & 1,52 & Elastis & 3,81 & Elastis \\
\hline Lubuk Linggau & 1,82 & Elastis & 0,07 & Inelastis & 0,46 & Inelastis & 0,92 & Inelastis & $-1,66$ & Elastis \\
\hline
\end{tabular}

Sumber: Data Olahan, 2017

Keterangan: *) Data belum tersedia disebabkan kabupaten PALI dan Musi Rawas Utara baru dimekarkan pada tahun 2014

Dari tabel di atas, elastisitas penyerapan tenaga kerja pada masing-masing kabupaten dan kota di Sumatera Selatan berfluktuasi selama periode 2011-2015. Beberapa kabupaten/kota memiliki nilai elastisitas penyerapan tenaga kerja elastis dan ada pula yang inelastis selama periode tersebut.

Elastisitas yang berkategori elastis dengan angka positif menunjukkan bahwa terjadi pertumbuhan penyerapan tenaga kerja di kabupaten/kota tersebut pada periode itu serta persentase pertumbuhan penyerapan tenaga kerja lebih besar dari persentase pertumbuhan ekonominya. Kondisi ini adalah kondisi yang paling diharapkan terjadi dalam suatu perekonomian karena hal ini dapat menggambarkan bahwa pertumbuhan ekonomi telah mampu meningkatkan aktivitas dalam sektor usaha sehingga penggunaan tenaga kerja bertambah akibat aktivitas sektor-sektor ekonomi berjalan dinamis atau jumlah lapangan kerja baru yang meningkat.

Elastisitas yang berkategori inelastis dengan angka positif menunjukkan bahwa masih terjadi pertumbuhan penyerapan tenaga kerja di kabupaten/kota tersebut pada periode itu akan tetapi persentase pertumbuhan penyerapan tenaga kerja lebih kecil dari persentase pertumbuhan ekonominya. Kondisi ini kurang menguntungkan bagi suatu perekonomian karena hal ini dapat menggambarkan bahwa pertumbuhan ekonomi belum berperan efektif dalam meningkatkan aktivitas sektor-sektor usaha sehingga penggunaan tenaga kerja baru atau pembukaan lapangan kerja baru relatif masih sedikit. Pada kondisi ini biasanya angka pengangguran relatif masih tinggi akibat masih sedikitnya lapangan kerja yang dibuka sementara jumlah angkatan kerja terus bertambah.

Elastisitas berkategori inelastis dengan angka negatif menunjukkan bahwa tidak terjadi pertumbuhan penyerapan tenaga kerja justru terjadi pengurangan jumlah tenaga kerja dibanding tahun sebelumnya. Persentase pengurangan tenaga kerja yang terjadi lebih kecil dari persentase pertumbuhan ekonomi yang tercipta. Kondisi ini tidak baik bagi perekonomian karena pengurangan tenaga kerja dapat berarti peningkatan angka pengangguran. Hal ini biasanya 
terjadi karena pertumbuhan ekonomi yang melambat sehingga kurang bergairahnya sektorsektor usaha lalu terdapat perusahaan-perusahaan yang melakukan efisiensi dengan mengurangi tenaga kerjanya.

Elastisitas berkategori elastis dengan angka negatif menunjukkan bahwa tidak terjadi pertumbuhan penyerapan tenaga kerja justru terjadi pengurangan jumlah tenaga kerjadalam jumlah yang relatif cukup besar dibanding periode sebelumnya. Persentase pengurangan penyerapan tenaga kerja yang terjadi melebihi persentase pertumbuhan ekonomi yang terjadi pada periode tersebut. Kondisi ini merupakan keadaan paradoks dan sangat tidak menguntungkan bagi perekonomian. Dikatakan paradoks adalah keadaan dimana terjadi pertumbuhan ekonomi pada periode tersebut namun di saat yang sama tidak terjadi penambahan penyerapan tenaga kerja bahkan terjadi pengurangan jumlah tenaga kerja yang bekerja secara besar-besaran dalam perekonomian. Hal ini dapat dimungkinkan apabila sektor usaha dalam perekonomian telah menggunakan teknologi canggih yang sebagian besar perannya mampu menggantikan peran tenaga manusia sehingga tenaga kerja terus berkurang atau tidak dipakai sama sekali. Kondisi lain yang mungkin terjadi adalah terjadinya krisis ekonomi yang menyebabkan pertumbuhan ekonomi terus melambat dari periode sebelumnya sehingga mengakibatkan timbulnya kelesuan dalam dunia usaha. Kelesuan dunia usaha ini dapat menyebabkan adanya rasionalisasi pada sektor perusahaansehingga perusahaan sangat mungkin akan menutup cabang-cabang usaha mereka akibat tekanan biaya produksi lalu kemudian melakukan PHK terhadap tenaga kerja mereka.

Tabel berikut ini memberikan gambaran jelas tentang kategori elastisitas pada masingmasing kabupaten/kota di Sumatera Selatan selama periode 2011-2015.

Tabel 4.3

Penggolongan Kabupaten/Kota Berdasarkan Kategori Elastisitas Penyerapan Tenaga Kerja

\begin{tabular}{|c|c|c|c|c|c|c|}
\hline \multirow{2}{*}{ No. } & \multirow{2}{*}{$\begin{array}{c}\text { Kategori } \\
\text { Elastisitas }\end{array}$} & \multicolumn{5}{|c|}{ Kabupaten/Kota } \\
\hline & & 2011 & 2012 & 2013 & 2014 & 2015 \\
\hline 1 & $\begin{array}{l}\text { Elastis } \\
\text { dengan } \\
\text { angka } \\
\text { positif }\end{array}$ & $\begin{array}{l}\text { - Ogan } \\
\text { Komering } \\
\text { Ulu } \\
\text { - Ogan } \\
\text { Komering } \\
\text { Ilir } \\
\text { - Musi } \\
\text { Banyuasin } \\
\text { - Empat } \\
\text { Lawang } \\
\text { - Prabumulih } \\
\text { - Lubuk } \\
\text { Linggau }\end{array}$ & $\begin{array}{l}\text { - Musi Rawas } \\
\text { - OKU Selatan } \\
\text { - Ogan Ilir } \\
\text { - Pagar Alam }\end{array}$ & - & $\begin{array}{l}\text { - Ogan } \\
\text { Komering } \\
\text { Ulu } \\
\text { - Musi } \\
\text { Banyuasin } \\
\text { - Banyuasin } \\
\text { - OKU } \\
\text { Selatan } \\
\text { - Palembang } \\
\text { - Pagar } \\
\text { Alam }\end{array}$ & $\begin{array}{l}\text { - Ogan } \\
\text { Komering } \\
\text { Ulu } \\
\text { - Lahat } \\
\text { - OKU } \\
\text { Timur } \\
\text { - Empat } \\
\text { Lawang } \\
\text { - Prabumulih } \\
\text { - Pagar } \\
\text { Alam }\end{array}$ \\
\hline 2. & $\begin{array}{l}\text { Inelastis } \\
\text { dengan } \\
\text { angka } \\
\text { positif }\end{array}$ & $\begin{array}{l}\text { - Muara Enim } \\
\text { - Musi Rawas } \\
\text { - Banyuasin } \\
\text { - OKU Timur } \\
\text { - Palembang }\end{array}$ & $\begin{array}{l}\text { - Muara Enim } \\
\text { - Lahat } \\
\text { - OKU Timur } \\
\text { - Empat } \\
\text { Lawang } \\
\text { - Lubuk } \\
\text { Linggau }\end{array}$ & $\begin{array}{l}\text { - Ogan } \\
\text { Komering } \\
\text { Ilir } \\
\text { - Palembang } \\
\text { - Prabumulih } \\
\text { - Lubuk } \\
\text { Linggau }\end{array}$ & $\begin{array}{l}\text { - Ogan } \\
\text { Komering } \\
\text { Ilir } \\
\text { - Muara } \\
\text { Enim } \\
\text { - Lahat } \\
\text { - Musi } \\
\text { Rawas } \\
\text { - Ogan Ilir } \\
\text { - OKU }\end{array}$ & $\begin{array}{l}\text { - } \text { Musi } \\
\text { Banyuasin } \\
\text { - OKU } \\
\text { Selatan } \\
\text { - Palembang }\end{array}$ \\
\hline
\end{tabular}




\begin{tabular}{|c|c|c|c|c|c|c|}
\hline & & & & & $\begin{array}{l}\text { Timur } \\
\text { - Prabumulih } \\
\text { - Lubuk } \\
\text { Linggau }\end{array}$ & \\
\hline 3. & $\begin{array}{l}\text { Elastis } \\
\text { dengan } \\
\text { angka } \\
\text { negatif }\end{array}$ & $\begin{array}{l}\text { - Ogan Ilir } \\
\text { - Pagar Alam }\end{array}$ & $\begin{array}{l}\text { - Ogan } \\
\text { Komering } \\
\text { Ulu } \\
\text { - Banyuasin }\end{array}$ & $\begin{array}{l}\text { - Musi } \\
\text { Banyuasin } \\
\text { - OKU Timur } \\
\text { - Empat } \\
\text { Lawang } \\
\text { - Pagar Alam }\end{array}$ & - & $\begin{array}{l}\text { - Ogan } \\
\text { Komering } \\
\text { Ilir } \\
\text { - Muara } \\
\text { Enim } \\
\text { - Musi } \\
\text { Rawas } \\
\text { - Lubuk } \\
\text { Linggau }\end{array}$ \\
\hline 4. & $\begin{array}{l}\text { Inelastis } \\
\text { dengan } \\
\text { angka } \\
\text { negatif }\end{array}$ & $\begin{array}{l}\text { - Lahat } \\
\text { - OKU } \\
\text { Selatan }\end{array}$ & $\begin{array}{l}\text { - Ogan } \\
\text { Komering Ilir } \\
\text { - Musi } \\
\text { Banyuasin } \\
\text { - Palembang } \\
\text { - Prabumulih }\end{array}$ & $\begin{array}{l}\text { - Ogan } \\
\text { Komering } \\
\text { Ulu } \\
\text { - Muara Enim } \\
\text { - Lahat } \\
\text { - Musi Rawas } \\
\text { - Banyuasin } \\
\text { - OKU Selatan } \\
\text { - Ogan Ilir }\end{array}$ & - & $\begin{array}{l}\text { - Banyuasin } \\
\text { - Ogan Ilir }\end{array}$ \\
\hline
\end{tabular}

\section{Sumber: Data Olahan, 2017}

Berdasarkan tabel di atas, perbandingan nilai elastistas antar kabupaten/kota setiap tahunnya berbeda-beda. Namun dapat ditarik kesimpulan bahwa selama tahun 2011-2015 pertumbuhan penyerapan tenaga kerja di kabupaten/kota Provinsi Sumatera Selatan relatif belum stabil. Pertumbuhan ekonomi belum konsisten untuk menjadi salah satu faktor pemicu meningkatnya penyerapan tenaga kerja secara stabil di kabupaten/kota di Sumatera Selatan.

Penyerapan tenaga kerja di Sumatra Selatan yang terbesar adalah terjadi pada sektor pertanian diikuti kemudianpada sektor perdagangan dan jasa-jasa. Berikut ini disajikan tabel yang tetang Persentase Jumlah Tenaga Kerja Berdasarkan Lapangan UsahaProvinsi Sumatera Selatan Tahun2012-2015.

Tabel 4.4

Persentase Jumlah Tenaga Kerja Berdasarkan Lapangan Usaha Provinsi Sumatera Selatan Tahun 2012-2015

\begin{tabular}{|c|c|c|c|c|}
\hline Lapangan Usaha & 2012 & 2013 & 2014 & 2015 \\
\hline \multicolumn{5}{|l|}{ Sektor Primer } \\
\hline - Pertanian & 56,37 & 54,86 & 53,37 & 54,74 \\
\hline - Pertambangan & 1,38 & 1,49 & 1,02 & 1,56 \\
\hline \multicolumn{5}{|l|}{ Sektor Sekunder } \\
\hline - Industri & 5,58 & 4,48 & 5,05 & 4,7 \\
\hline - Listrik, Air, dan Gas & 0,19 & 0,19 & 0,17 & 0,17 \\
\hline
\end{tabular}




\begin{tabular}{|c|c|c|c|c|c|}
\hline \multicolumn{2}{|l|}{ - Bangunan } & 4,01 & 3,82 & 4,32 & 4,54 \\
\hline \multicolumn{6}{|l|}{ Sektor Tersier } \\
\hline \multicolumn{2}{|l|}{ - Perdagangan } & 14,59 & 15,46 & 11,96 & 16,82 \\
\hline \multicolumn{2}{|l|}{ - Angkutan/Komunikasi } & 3,43 & 3,63 & 5,65 & 3,64 \\
\hline \multicolumn{2}{|l|}{ - Keuangan } & 2,03 & 2,24 & 1,72 & 1,61 \\
\hline \multicolumn{2}{|l|}{ - Jasa-Jasa } & 12,63 & 13,44 & 9,76 & 12,22 \\
\hline \multirow{2}{*}{ Jumlah } & $\%$ & 100 & 100 & 100 & 100 \\
\hline & $\mathbf{N}$ & 3.532.932 & 3.524 .883 & 3.692 .806 & 3.695 .866 \\
\hline
\end{tabular}

Sumber: BPS, 2016

Tabel 4.4 di atas mengungkapkan bahwa penyerapan tenaga kerja di Sumatera Selatan selama tahun 2012-2015 paling banyak terjadi pada lapangan usaha pertanian. Rata-rata persentase penyerapan tenaga kerja di sektor pertanian selama tahun 2012-2015 adalah 54,8 persen dari total jumlah tenaga kerja. Hal ini berarti lebih dari separuh jumlah keseluruhan tenaga kerja yang ada di Sumatera Selatan bekerja di sektor pertanian. Besarnya penyerapan tenaga kerja terjadi pada daerah-daerah kabupaten yang nota bene sebagian besar wilayahnya merupakan pedesaan.

Kontribusi penyerapan tenaga kerja terbesar selanjutnya adalah pada sektor usaha perdagangan dan jasa-jasa (termasuk di dalamnya usaha hotel dan restoran). Sektor perdagangan menyerap tenaga kerja rata-rata 14,71 persen sedangkan sektor jasa-jasa sebesar 12,01 persen. Sektor usaha yang paling kecil menyerap tenaga kerja adalah sektor listrik, air dan gas dengan rata-rata persentase sebesar 0,18 persen dari total tenaga kerja di Sumatera Selatan. Penyerapan tenaga kerja pada sektor ini banyak terjadi di daerah perkotaan seperti Kota Palembang, Prabumulih, Pagar Alam, dan Lubuk Linggau.

Sektor pertanian memang masih menjadi sektor utama dalam perekonomian Sumatera Selatan. Menurut BPS (2016: 67), lapangan usaha pertanian mencakup sublapangan usaha pertanian, kehutanan, dan perikanan yang terdiri atas tanaman pangan, tanaman holtikutura, tanaman perkebunan, peternakan, jasa pertanian dan perburuan, sublapangan usaha kehutanan dan penebangan kayu, serta sublapangan usaha perikanan. Lapangan usaha ini masih menjadi tumpuan harapan dalam penyerapan tenaga kerja.

\section{KESIMPULAN}

Berdasarkan pembahasan di atas dapat ditarik beberapa kesimpulan sebagai berikut:

1. Berdasarkan hasil pembahasan, didapati bahwa selama periode 2011-2015 elastisitas tenaga kerja Provinsi Sumatera Selatan lebih banyak masuk dalam kategori inelastis, hanya pada tahun 2013 kategorinya elastis. Hal ini berarti rata-rata pertumbuhan ekonomi selama periode tersebut tidak terlalu mendorong respon pertumbuhan jumlah tenaga kerja. Persentase pertumbuhan penyerapan tenaga kerja lebih kecil dari persentase pertumbuhan ekonomi.

2. Hasil pembahasan juga menemukan bahwa perbandingan nilai elastistas antar kabupaten/kota setiap tahunnya selalu berbeda-beda. Namun dapat ditarik kesimpulan bahwa selama tahun 2011-2015 pertumbuhan penyerapan tenaga kerja di kabupaten/kota Provinsi Sumatera Selatan relatif belum stabil. Pertumbuhan ekonomi belum konsisten untuk menjadi salah satu faktor pemicu meningkatnya penyerapan tenaga kerja secara stabil di beberapa kabupaten/kota di Sumatera Selatan. 


\section{DAFTAR PUSTAKA}

Asaddin, Fuad dan Mansoer, Faried Wijaya. 2001. Pertumbuhan Ekonomi dan Kesempatan Kerja: Terapan Model Kebijakan Prioritas Sektoral Untuk Kalimantan Timur. Jurnal Riset Akuntansi, Manajemen, dan Ekonomi. Vol. 1 No. 1.

Afrida, BR. 2003. Ekonomi Sumber Daya Manusia. Jakarta: Ghalia Indonesia

Arsyad, Lincoln. 2010. Ekonomi Pembangunan. Yogyakarta: Unit Penerbit dan Percetakan STIM YKPN Yogyakarta.

Badan Pusat Statistik. 2016. Indikator Pembangunan Sumatera SelatanTahun 2016. BPS.Palembang

Badan Pusat Statistik. 2015. Statistisk Daerah Sumatera Selatan Tahun 2015. BPS. Palembang

Badan Pusat Statistik. 2016. Statistisk Daerah Sumatera Selatan Tahun 2016. BPS.Palembang

Badan Pusat Statistik. 2015. Situasi Ketenagakerjaan Sumatera Selatan Tahun 2015. BPS.Palembang

Badan Pusat Statistik. 2016. Situasi Ketenagakerjaan Sumatera Selatan Tahun 2016. BPS.Palembang

Badan Pusat Statistik. 2011. Provinsi Sumatera Selatan Dalam Angka Tahun 2011. BPS. Palembang

Badan Pusat Statistik. 2012. Provinsi Sumatera Selatan Dalam Angka Tahun 2012. BPS. Palembang

Badan Pusat Statistik. 2013. Provinsi Sumatera Selatan Dalam Angka Tahun 2013. BPS. Palembang

Badan Pusat Statistik. 2014. Provinsi Sumatera Selatan Dalam Angka Tahun 2014. BPS. Palembang

Badan Pusat Statistik. 2015. Provinsi Sumatera Selatan Dalam Angka Tahun 2015. BPS. Palembang

Badan Pusat Statistik. 2016. Provinsi Sumatera Selatan Dalam Angka Tahun 2016. BPS. Palembang

Budiman, Arief. 1995.Teori Pembangunan Dunia Ketiga. PT. Gramedia Pustaka Utama. Jakarta.

Case, dan Fair. 2005. Prinsip-prinsip Ekonomi Mikro, Edisi IX, (Alih Bahasa Barlian Muhamad). PT INDEKS. Jakarta.

Chusna, Arifatul. 2013. Pengaruh Laju Pertumbuhan Sektor Industri, Investasi, dan Upah Terhadap Penyerapan Tenaga Kerja Sektor Industri Di Provinsi Jawa Tengah Tahun 1980-2011. Economics Development Analysis Journal 2 (3) ISSN 22526889.Universitas Negeri Semarang. Semarang.

Darman. 2013. Pengaruh Pertumbuhan Ekonomi Terhadap Tingkat Pengangguran: Analisis Hukum Okun. Journal The Winners, vol. 14 no. 1, Maret 2013: 1-12.

Dimas dan Woyanti, Nenik.2009. Penyerapan Tenaga Kerja di DKI Jakarta.Jurnal Bisnis dan Ekonomi (JBE), Vol. 16, No. 1, hal.32-41. Fakultas Ekonomi Universitas Diponegoro.Semarang.

Dornbusch, R., Fischer, S., Startz, R. 2001. Makroekonomi.Media Global Edukasi. Jakarta.

Dumairy.2004. Matematika Terapan Untuk Bisnis dan Ekonomi.BPFE Yogyakarta.Yogyakarta.

Kuncoro, Haryo. 2002." Upah Sistem Bagi Hasil dan Penyerapan Tenaga Kerja." Jurnal Ekonomi Pembangunan. Kajian Ekonomi Negara Berkembang, Vol. 7 No. 1, 2002. ISSN:1410-2641.

Mankiw, Mankiw, N.Gregory. 2007. Makroekonomi, Edisi Keenam. Erlangga.Jakarta.

Mahalli, Kasyful. 2008. Kesempatan Kerja dan Pertumbuhan Ekonomi Kota Medan. WAHANA HIJAU Jurnal Perencanaan \& Pengembangan Wilayah, Vol.3, No.3, April 2008. Medan.

Pangastuti, Yulia. 2015. Analisis Faktor Faktor Yang Mempengaruhi Penyerapan Tenaga Kerja Di Provinsi Jawa Tengah Tahun 2008-2012.Economics Development Analysis Journal 4 (2) 2015.Universitas Negeri Semarang. Semarang. 
Simanjuntak, Payaman. J. 2001. Pengantar Ekonomi Sumberdaya Manusia. Lembaga Penerbit FEUI. Jakarta.

Sitanggang, I. R. dan Nachrowi, N.D. 2004. Pengaruh Struktur Ekonomi pada Penyerapan Tenaga Kerja Sektoral: Analisis Model demometrik di 30 Propinsi pada 9 Sektor di Indonesia. Jurnal Ekonomi dan Pembangunan Indonesia.Vol. 5.No. 1.FEUI. Jakarta.

Subri, Mulyadi. 2003. Ekonomi Sumber Daya Manusia. PT Raja Grafindo Persada. Jakarta.

Sukirno, Sadono, 2010. Teori Pengantar Makroekonomi, Edisi Ketiga. Raja Grafindo. Jakarta.

Sobita, Nindya Eka dan Suparta,.2014. Pertumbuhan Ekonomi Dan Penyerapan Tenaga Kerja Di Provinsi Lampung Jurnal Ekonomi PembangunanVol.3, N0 2, Juli 2014. Universitas Lampung. Lampung

Tarigan, Robinson. 2007. Ekonomi Regional: Teori dan Aplikasi. Bumi Aksara. Jakarta.

Todaro, Michael P. Dan Stephen C. Smith. 2014. Pembangunan Ekonomi, 12 ed. Erlangga. Jakarta.

Yanurwardhani W, Dian dan Woyanti, Nenik. 2009. Analisis Pengaruh Faktor Ekonomi Terhadap Penyerapan Tenaga Kerja Pada Industri Kecil Tempe Di Kota Semarang.Media ekonomi dan manajemen vol 20. No 2 juli 2009, ISSN: 0854-1442. Semarang. 